\title{
Marital Property Laws and Women's Labour Supply
}

\author{
Stephanie Lluis*and Yazhuo (Annie) $\operatorname{Pan}^{\dagger}$
}

\begin{abstract}
In this paper we study whether and if so how changes in the marital property law following the amendment of the Civil Code of Quebec to improve economic equality between spouses impacted household labour supply and individuals' marital decisions. We exploit detailed information on individual labour market and marital status from the Labour Force Survey to analyze short-term changes in labour supply and marital decisions before and after the reforms in Quebec relative to other provinces that did not experience the changes in the marital property law over that time period. Investigating the labour supply and marital decisions' responses to a policy changing the distribution of resources between men and women may assist welfare agencies in the design of family reforms and more generally, help further reduce women's entry into poverty. Furthermore, analyzing whether the Quebec marital property law changed the demographic mix of couples may further inform policymaker about possible ways to improve gender equality.
\end{abstract}

JEL classification: C21, H75, J12, J22

Keywords: Marital property law, labour supply, divorce, assortative matching, Quebec Civil Code Amendment

*Department of Economics, University of Waterloo, Waterloo, ON. N2L-3G1. Canada; E-mail: slluis@uwaterloo.ca

$\dagger$ Department of Economics, University of Waterloo, Waterloo, ON. N2L-3G1. Canada; E-mail: y68pan@uwaterloo.ca 


\section{Introduction}

Since the 1980s, women's labour force participation has increased substantially, especially among married women. ${ }^{1}$ In addition, the share of two-earner couples and the contribution of the wife to household income has also substantially increased. ${ }^{2}$ These trends reflect interactions between labour supply and marital decisions evolving as a result of social and economic policies (e.g. divorce law and child-care service reforms) changing attitudes toward women at work and incentivizing employment. Moreover, who controls family resources affects not only consumption expenditures (Lundberg et al. (1997); Ward-Batts (2008)) but also each spouse's time allocation (Schultz (1990)). By creating laws and policies affecting the distribution of resources between men and women, the government has the potential to promote outcomes that help to reduce women's entry into poverty and improve well-being inside and outside marriage (Smock et al. (1999); Bedard and Deschenes (2005)).

In this paper, we study the effect of a redistributive divorce law on the labour supply of married women and on couples' marital decisions in Canada. The 1989 amendment of the Civil Code of Quebec was made to favour economic equality between spouses by imposing an equal division of the family patrimony (family house, vehicles and the spouses' retirement savings). This change created an unexpected shift in the bargaining power of the spouse with relatively lower investment in the family assets, typically the wife. ${ }^{3}$ The potential increase in the share of the family assets at divorce associated with the redistributive change could negatively impact the labour supply of married women, especially among long-term married couples more likely to have accumulated family assets. The redistributive change is also likely to impact the marital decisions of couples already married or thinking about marriage as the unexpected bargaining power shift may have created unresolvable tensions or changed expectations about the financial implications of investing in a marriage.

We use a difference-in-difference approach and exploit information on female labour supply and marital status from the Canadian Labour Force Survey data to analyze outcomes before and after the reforms in Quebec, relative to other provinces. Our main research

\footnotetext{
${ }^{1}$ According to Statistics Canada Labour Force Survey data (LFS), the labour force participation (LFP) rate among Canadian women aged 15 years and older increased by about 10 percentage points (from $48.5 \%$ in 1978 to $58.1 \%$ in 1998) over the two decades following the start of the first workplace and family reforms. The LFP rate of married women increased by 15 percentage points (from $47.1 \%$ in 1978 to $62.3 \%$ in 1998), while the rate (already high) increased much less among divorced/separated women (from $60.3 \%$ in 1978 to $64.6 \%$ in 1998).

${ }^{2}$ The proportion of two-earner couples has increased from $52.1 \%$ to $59.8 \%$ and the wife's contribution from $26 \%$ to $32.8 \%$ between 1979 and 1998 (Chiappori et al. (2005) based on US data from the BLS).

${ }^{3}$ According to the Canadian Census in 1981 and 1986, the average contribution of the husband to family income was $70.20 \%$ (48.74\% corresponds to labour income and $21.46 \%$ to non-labour income). In the $1990 \mathrm{~s}$, the average contribution of the husband to family income only reduced to $64.29 \%$ ( $40.90 \%$ corresponds to labour income and $23.39 \%$ to non-labour income) so the contribution of the wife increased but the husband's contribution still represented the majority of the family wealth. Regarding house ownership by gender among couples, $94.14 \%$ of house owners were men and only $5.86 \%$ were women in the $1980 \mathrm{~s}$. In the $1990 \mathrm{~s}$, $89.51 \%$ of them were men and $10.59 \%$ were women.
} 
question applies to three outcomes: Did the change in the redistribution of resources within couples influence 1) the labour force participation and hours of work of married women, 2) divorce transitions, and 3), the marital decision of young and never married individuals regarding whom to marry.

The period of the Quebec marital property law change is interesting because over the mid 1980s to mid 1990s, women's involvement in the workplace was rapidly growing. On the other hand, finding the ideal dataset covering that time period is challenging. The Labour Force Survey (LFS) data provides demographic and labour market information over several years of data covering the pre- and post- treatment periods. However, the question related to marital status does not distinguish marriage from common law unions until the mid 1990s which is after our main period of study. The distinction is available in the marital status question of the Canadian Census data but the information is available over only two years of the pre-intervention period $(1981,1986)$ leaving insufficient variations to exploit in a DiD estimation setting. We perform our main estimations using the LFS data but use the Census data for additional checks and conclude that our results are unlikely to be driven by the inclusion of common law couples. ${ }^{4}$

An advantage of the LFS data is that it contains detailed demographic and labour market information for a representative sample of Canadian households that we exploit to address our research questions. We use information on home ownership and education of each spouse to further analyze whether the effect of the Quebec marital property law change more strongly impacted the labour supply of married women for couples with greater assets (home owners as opposed to renters) and of married women with lower earnings potential (such as less education) suggesting a weaker bargaining position prior to the law change. We also take advantage of the panel format of the LFS data to measure the dynamics of divorce transitions of couples married before and after the law change. We use information on age and the age of a couple's children whenever relevant to further identify long-term couples more likely to respond to the policy change. The household format of the LFS allows us to compare the profile of each member of the household to estimate the extent of assortative matching among newly married couples. Finally, we employ additional selection criteria to address possible confounding effects coming from other policy changes that took place in Quebec around 1989 (e.g. an amendment to the social assistance policy, a new family allowance policy and a parental wage assistance program). Our results are robust to these checks as well as a falsification test based on an analysis of the Quebec law change

\footnotetext{
${ }^{4}$ While the literature notes a greater incidence rate of common law unions in Quebec in the mid 1980s relative to other provinces (Statistics Canada (1997); Le Bourdais and Lapierre-Adamcyk (2004)), the trends in the rate of incidence of common law unions are in fact very similar before the mid 1990s and only started to change in Quebec relative to the rest of Canada in the later part of the 1990s. Our results on the other hand show that the significant labour supply impact of the Quebec marital property law is found in the earlier part of the 1990s.
} 
on single women for whom a labour market response to the Quebec marital property law change is not expected.

The literature on the economics of the family is broad ranging from the theoretical modelling of family decisions to empirical investigations of societal and legal determinants of marriage and divorce rates. The collective bargaining theory of marital decisions emphasize the importance of an intra-household sharing mechanism and distribution factors that impact each spouse's labour and consumption decisions within the household (Manser and Brown (1980); McElroy and Horney (1981); Chiappori (1988); Chiappori (1992); Browning and Chiappori (1998); Chiappori and Ekeland (2001); Chiappori et al. (2002)). In these models, a wife's labour supply is predicted to decrease when her bargaining power rises, where bargaining power is determined by human capital investments, ownership of assets (non-labour income), social networks, and by redistributive family laws. For example, reforms in divorce or marital property laws that redistribute household assets (or the future stream of income from such assets) in favour of one spouse (usually women), raise the spouse's bargaining power thereby reducing their labour supply (Agarwal (1997); Chiappori et al. (2002)).

The empirical literature on the economics of the family that studies the link between marital property divorce laws and female labour supply is relatively small and focused on the US (Peters (1986); Parkman (1992); Gray (1998); Stevenson (2008); Voena (2015)). A few studies have analyzed marital property reforms in other countries (Kapan et al. (2008); Brassiolo (2013); Ziparo (2017)). Overall, and especially among the more recent studies ${ }^{5}$, the results generally support the collective model's prediction that a redistributive divorce law favouring one spouse, by increasing her bargaining power within the household, reduces her labour supply. In the US, Voena (2015) explores panel data on married women who stayed married throughout the sample period and finds that their employment declines in states where the unilateral divorce imposes equal division of property and the intra-household bargaining power shifts to their benefit. Similarly, Kapan et al. (2008) and Brassiolo (2013) analyze reforms in property division regimes in England and Wales, and Spain, respectively, applying a difference-in-difference methodology to panel data. The empirical results in both studies show that labour supply decreased for wives who married before the policy changes and stayed married afterwards, when the property division regime became favourable to them. It is also worth noting that the work disincentive effect in these three studies is estimated shortly after the reform, but long-term effects may be different (Ziparo (2017)).

\footnotetext{
${ }^{5}$ Among the earlier studies that have investigated how the adoption of unilateral divorce influences women's labour supply in the United States, Gray (1998), estimating data at two points in time, finds that a wife's labour supply increases with her increasing bargaining position (as measured by the adoption of the unilateral divorce law), which is inconsistent with the prediction of the collective model. Stevenson (2008), however, criticized Gray's results emphasizing the idea that variations in bargaining power within the household might be captured by cross-states variations in property division rules than the adoption of unilateral divorce.
} 
Moreover, divorce reforms may have differential impact on couples' decisions depending on marriage duration as divorce risk declines with increasing returns from marriage investments (Simard-Duplain (2018)). We also hypothesize that a redistributive divorce law is likely to have stronger (short-term) effects coming from unanticipated wealth changes resulting from an equal sharing rule among more mature marriages whose accumulated assets are large.

Our study complements the literature in three ways. First, we test whether the Civil Code reform in Quebec lead to a reduction in the labour supply of married women as a result of increased bargaining power consistent with the prediction of the collective model of household bargaining. In the Canadian context, we are able to isolate the impact of the marital property regulations determined at the provincial level from the no-fault divorce law that was adopted nationwide. We exploit a unique change in the marital property law that took place only in Quebec and no other provinces thereby allowing us to differentiate the time trends from the law-specific effects. Second, the rich information provided in our data allows us to further study the bargaining power implications of the redistributive divorce law by further estimating the impact of Quebec's reforms by the educational attainment of the wife and property ownership of the couple. Third, we emphasize selection issues associated with any analysis of the impact of a matrimonial regime amendment on the labour supply of married women who stayed married after the reform by estimating the impact of the Quebec Civil Code reform on marital decisions and on measures of assortative mating. Family law reforms not only influence the decision to marry or divorce, they are also likely to affect couples' decisions of whom to marry by inducing people to marry a partner with a similar background (assortative matching). Some studies have explored whether couples show similarity in educational attainment and cultural background in the United States (Mare (1991); Kalmijn (1994); Pencavel (1998); Watson et al. (2004)). Our study adds to this literature by exploring whether a law change towards more equitable sharing of resources among spouses at dissolution increases the likelihood that individuals with the same financial profile will decide to marry.

The remainder of the study is organized as follows: The next Section presents an overview of the literature and the institutional background pertinent to the present study and question. In particular, Section 2.1 reviews the literature on household labour supply and family laws, and Section 2.2 describes the marital property law in Quebec as well as the rest of Canada. Section 3 explains the data, measurements and provides descriptive statistics. Section 4 presents the methodology used in this paper as well as results. Section 5 concludes the work and discusses future steps. 


\section{Literature and Institutional Background}

\subsection{Theoretical and Empirical Studies}

The significant growth in labour force participation and post-secondary education of women over the last decades strengthened their influence over economic decisions within the household. In parallel, the modelling of intra-household decision-making developed rapidly; moving away from the traditional unitary model which assumes common preferences and single pooling of resources, the models introduced mechanisms reflecting the sharing and distribution of resources within the household and in particular, the concept of a couple's bargaining power (Thomas (1990); Hoddinott and Haddad (1995); Lundberg et al. (1997). ${ }^{6}$

Because the internal allocation process of the intra-household resources among family members cannot be identified under the single decision-making unit assumption of the unitary model (Chiappori (1992)), alternative multi-agent household models have developed in which household members' preferences depend on each other. Manser and Brown (1980) and McElroy and Horney (1981) developed the cooperative bargaining model based on Nash bargaining theory in which husbands and wives have heterogeneous utility functions that depend on their own consumption and leisure, as well as on shared household public goods. They cooperate in intra-household decisions regarding the labour market, consumption, and the sharing of public goods.

The collective model generalizes the mechanism behind the cooperative bargaining model (Chiappori (1988); Chiappori (1992); Browning and Chiappori (1998); Chiappori and Ekeland (2001); Chiappori et al. (2002); Blundell et al. (2007)). The model relies on the assumption that households' decisions are Pareto-efficient and the idea that given preferences that can either be "egotistic" or "caring", it is possible to define a sharing rule identifying how household ressources are allocated to household members. ${ }^{7}$ The decision process involves two stages: first, all household members decide a "sharing rule" to share the household non-labour income, according to factors such as the wage rate, non-labour income, and their attributes; second, each member individually chooses his/her own labour involvement and consumption subject to the corresponding budget constraints and the sharing rule.

Additionally, the "distribution factors" introduced in the collective model framework permit an analysis of the influence of the intra-household decision-making in the presence of exogenous shocks generated by quasi-natural experiments such as legislation changes

\footnotetext{
${ }^{6}$ For example, Lundberg et al. (1997) reject these hypotheses based on analyzing a 1979 child benefit policy reform in the United Kingdom that changed this child financial subsidy recipients from fathers to mothers. They find that this income redistribution induced families to spend more on women's and children's clothing, while less on men's clothing. These findings suggest that wives usually place more weight on their children and families' expenditures than husbands do.

${ }^{7}$ Under the egotistic preference, a person's utility only depends on his/her own consumption and leisure. In contrast, under the caring assumption, a person's preference depends on both his/her own and the spouse's utility (Chiappori et al. (2002)).
} 
(Chiappori et al. (2002); Kapan et al. (2008)). ${ }^{8}$ The collective model predicts that a wife's participation in the labour market decreases if she gains more intra-household bargaining power. The same prediction is also found in the dynamic version of the collective model presented inVoena (2015).

The empirical literature that exploited the exogeneity of family-related policy changes (enhancing women's bargaining position within a marriage and their financial welfare after divorce) investigated the impact of these law reforms on women's labour supply (Peters (1986); Parkman (1992); Gray (1998); Genadek et al. (2007); Stevenson (2008); Kapan et al. (2008); Brassiolo (2013); Voena (2015); Ziparo (2017)). Overall, the results are generally supportive, especially among the more recent studies, of the collective model's prediction that a redistributive divorce law favouring one spouse, by increasing her bargaining power within the household, reduces her labour supply.

In the U.S., several researchers explored the impact of the adoption of unilateral divorce on women's labour supply (Peters (1986); Parkman (1992); Gray (1998); Chiappori et al. (2002); Genadek et al. (2007); Stevenson (2008); Voena (2015)). Some early studies find a positive association between the bargaining power and wives' labour supply (Peters (1986); Parkman (1992); Gray (1998)). For instance, Peters (1986) and Parkman (1992) indicate a positive impact of the unilateral divorce law on female labour force participation. Using data at two points in time, these results have been questioned by Gray (1998) who first finds an insignificant impact on women's labour supply as a result of this unilateral divorce law, without controlling for the marital property law in each state. After the marital property laws have been taken into account, he finds that married women in the community-property states, which strengthened wives' rights, are more likely to increase their labour supply; while wives in the common-law states, which weakened married women's rights, are more likely to decrease their labour supply ${ }^{9}$. This positive relationship is inconsistent with the prediction of the theoretical models ${ }^{1011}$. In contrast, a more recent study by Voena (2015),

${ }^{8}$ Chiappori et al. (2002) and Kapan et al. (2008) define the "distribution factors" as any exogenous variables that can influence the intra-household decision process without affecting individuals' preferences or budget constraints.

${ }^{9}$ In the community-property states, property accumulated during marriage is considered as community property. In contrast, in the common-law states, property accumulated during marriage by each spouse is his/her own property.

${ }^{10}$ Gray (1998) explains this contradiction with a shift in their allocated time from home production to the labour market. He indicates that a woman's non-labour time could consist of two parts: leisure and home production hours. Under this assumption, when her bargaining power increases, she will allocate more time to the labour market from her home production hours, rather than from her leisure time.

${ }^{11}$ Stevenson (2008), however, revisited this research and criticized the results in Gray (1998), indicating that the effects of the unilateral divorce law on wives' labour supply is independent of the property division rules in the state. Stevenson (2008) pointed out the omitted variable bias and potential problems of coding states by their property division regimes in Gray (1998) and indicates that married women increased their labour supply after the adoption of the unilateral divorce law, regardless of the marital property laws. Genadek et al. (2007) also suggest that the effect of the unilateral divorce law on wives' labour supply is independent of the property division rules in the states through analyzing the effects of this law change on 
found a negative relationship between the bargaining power and wives' labour supply. Exploring panel data with longer time periods compared to that of previous literature, Voena (2015) finds a decline in women's employment due to the unilateral divorce in equal division of property states, where the intra-household bargaining power shifts to their benefit. This finding is consistent with predictions of the collective model ${ }^{12}$.

Three studies focused on marital property division law reforms in other countries (Kapan et al. (2008); Brassiolo (2013); Ziparo (2017)) and the evidence across countries is also generally supportive of the collective model's prediction. Kapan et al. (2008) show that a property division regime reform in England and Wales, by giving a greater proportion of the total assets to the disadvantaged spouse, negatively impacted the labour supply of wives. Brassiolo (2013) examined two changes of the separation of property regime in Catalonia using a difference-in-difference approach and found similar negative employment outcomes for wives. ${ }^{13}$ Ziparo (2017) does not find a significant negative employment effect when comparing the labour supply responses of women married following a matrimonial regime reform in France in 1966 to that of women married before the policy changes. However, his study points to the different timing at which the pre- and post-reform impacts were measured. The work disincentive effect found in the other studies (Kapan et al. (2008); Brassiolo (2013); Voena (2015)) is estimated shortly after the reform, but long-term effects may be different. In addition, divorce reforms may have differential impact on couples' decisions depending on marriage duration as divorce risk declines with increasing returns from marriage investments (Simard-Duplain (2018)). We also hypothesize that a redistributive divorce law is likely to have stronger (short-term) effects coming from unanticipated wealth changes resulting from an equal sharing rule among more mature marriages whose accumulated assets are large.

In Canada, Ligon et al. (2003) analyzed the association between the matrimonial property law and female suicide. They find that the marriage-related legislation reforms, which enhanced women's rights, reduced married women's suicide. To our knowledge, there has been no empirical economic investigations of the impact of the 1989 Civil Code amendments in Quebec on women's labour supply. The objective of our study is to fill this gap.

Regarding the question of whether family-related law reforms affect individuals' marital decisions as well as assortative matching, some researchers explored the influence of adopting

married mothers and non-mothers' labour supply.

${ }^{12}$ Chiappori et al. (2002) also find that married women reduced their labour supply when the divorce laws enhanced their rights with the functional-form model in the collective model they developed.

${ }^{13}$ The changes to the separation of property regime in Catalonia were the following: in 1993, the financially weaker spouse would receive an economic compensation in the event of a divorce; in 1998, marital contracts could include marital property provisions when a marriage ends. The empirical results indicate that wives' labour supply reacted in the opposite way under these two reforms: it decreased when the first change improved wives' bargaining power, but increased after the second change, when the scope of the marriage contract canceled this improvement. 
unilateral divorce law or no-fault divorce law on divorce rates (Peters (1986); Allen (1998); Gray (1998); Friedberg (1998); González and Viitanen (2009); Brassiolo (2013)). Peters (1986) and Gray (1998) indicate that the adoption of unilateral divorce laws in the United States does not increase divorce rates. This finding is consistent with the Coase Theorem which suggests that the likelihood of divorce should be similar under either mutual consent or unilateral divorce laws if spouses can transfer resources to each other with insignificant cost. However, Friedberg (1998) has suggested that this legal shift in the United States increases individuals' likelihood of divorce. Allen (1998) and González and Viitanen (2009) also find this growing effects on divorce rates due to the adoption of no-fault divorce law in Canada and Europe, respectively. Brassiolo (2013) has analyzed an unexpected reform on marital property division in the event of a divorce in Spain. This study also suggests that this reform, which allows women to gain more bargaining power within marriage, has increased the divorce rate. Our paper investigates this question using Canadian 6-month panel data to more closely estimate how the Quebec redistributive divorce law affected individuals' marital status transitions. Many researchers have analyzed the issue of assortative matching, using various measurements, to indicate the level of similarity between spouses in the United States (Mare (1991); Kalmijn (1994); Pencavel (1998); Watson et al. (2004)). These measures include the differential of education, age, cultural background, political orientation, and emotional personality. Kalmijn (1994), Pencavel (1998), Watson et al. (2004) find that couples have shown similarity in educational attainment since the 1980s. Mare (1991) indicates that this fact was also true even before the 1980s using five decades data. Moreover, Watson et al. (2004) suggest that newlyweds have also shown significant similarity in other attributes such as age, cultural background, and political orientation. Our study add to this literature by exploring whether a law change towards more equitable sharing of resources among spouses at dissolution increases the likelihood that individuals with the same financial profile decide to marry. According to our knowledge, in Canada, no literature has exploited the exogeneity of legislation changes to analyze the impact of these law reforms on people's decisions about whom to marry.

\subsection{Marital property law in Canada}

In Canada, the marital property law in each province was reformed during the middle of the 19th century. Table A1 in Appendix A presents the marital property act in each province in 1989 (the year of the marital property law change in Quebec). Note that the titles of the marital property laws are different across provinces; for example, in Quebec, this law is called "family patrimony rules", however, Ontario uses "Family law Act" as the title. Each of these laws has been amended several times by its own provincial government. 


\section{Marital property law at divorce in Quebec before and after the 1989 Act}

From Appendix A Table A1, we see that in Quebec, the 1989 Act amended the Civil Code to favour economic equality between spouses. First, it created a concept of "family patrimony" and specified which kind of property should be included in this creation. Properties included in the family patrimony are (1) The houses where a family is living (2) Objects in the family's homes for furnishing or decorating (3) The motor vehicles for family's use (4) The retirement savings accounts. Second, the amendment specified that the value of the family patrimony should be equally divided between spouses after deducting any debts in the event of a divorce, even if some of the property does not belong to the common property. Third, any property excluded from the family patrimony is divided following the matrimonial regime rules, which is "partnership of acquests", or "separation as to property", or "community of property" depending on the couple's choices as well as the date of marriage (https://www.educaloi.qc.ca/en/capsules/ matrimonial-regimes-rules-managing-and-dividing-property $)^{14}$.

Before the 1989 Act, all properties were divided following the matrimonial regime rules. The new act created an unexpected change in the intra-household financial situation of couples where one spouse, typically the wife, has little ownership of and is less equally invested into the assets contributing to the family partimony. Despite the growing emancipation of women in the 1980s, by 1989, the husband was still typically the principal income earner, and the house was usually under the name of the husband (Gray (1998); Chiappori et al. (2002); Stevenson (2008)). According to our own calculations using the Canadian Census (1981, 1986, 1991 and 1996), the average contribution of the husband to family income was $70.20 \%$ ( $48.74 \%$ corresponds to labour income and $21.46 \%$ to non-labour income) in the $1980 \mathrm{~s}$. In the $1990 \mathrm{~s}$, the average contribution of the husband to family income only reduced to $64.29 \%$ ( $40.90 \%$ corresponds to labour income and $23.39 \%$ to non-labour income) so the contribution of the wife slightly increased but the husband's contribution still represented the majority of family wealth. Regarding house ownership among married people, only $5.86 \%$ were women in the $1980 \mathrm{~s}$. In the $1990 \mathrm{~s}$, only $10.59 \%$ were women ${ }^{15}$. As a result, wives with relatively

\footnotetext{
14 "If a couple signed a marriage contract in front of a notary, their matrimonial regime is the one stated in the contract. If they did not sign a marriage contract in front of a notary, or if their marriage contract doesn't mention a matrimonial regime, then the regime depends on when they were married. Community of property used to apply automatically to all couples married before July 1, 1970 who had not chosen a matrimonial regime in a notarized marriage contract. Spouses today can still choose the community of property regime in a marriage contract. Partnership of acquests applies automatically to all marriages in Quebec since July 1, 1970 if the spouses did not choose a matrimonial regime in a notarized marriage contract." (https://www.educaloi.qc.ca/en/capsules/dividing-your-property-overview; https:// www.educaloi.qc.ca/en/capsules/matrimonial-regimes-rules-managing-and-dividing-property; https://www.educaloi.qc.ca/en/capsules/matrimonial-regimes-community-property; https: //www.educaloi.qc.ca/en/capsules/matrimonial-regimes-partnership-acquests)

${ }^{15}$ In the Canadian Census, respondents are only surveyed to answer whether the dwellings they are living in are owned by a family member. Therefore, the house ownership of a respondent himself/herself can only be proxied. We use the information regarding whether a respondent is the primary household maintainer
} 
lower earnings potential who accumulated less into the payment of the family house, the car and with little pension income (having invested less time in the labour market and more time into home production) are at a disadvantage during property division at divorce under the rules of matrimonial regimes that failed to consider economic equality between spouses. Additionally, these assets (family home, vehicle, and pension plan) usually contribute a significant portion of the total family property. According to the Statistics Canada Survey of Consumer Finances and Survey of Financial Security, the share of the value of non-financial assets (home and vehicle) in total family assets was $47.90 \%$ in 1984, the share of the value of financial assets (such as pension plans and stocks) in total family assets was $21.10 \%$. In 1999, the share of the value of non-financial assets (home and vehicle) in total family assets was $45.80 \%$, the share of the value of financial assets (such as pension plans and stocks) in total family assets was $31.10 \%$. In summary, having an equal share of the family property after divorce is expected to improve women's bargaining power and economic conditions.

\section{Marital property law at divorce in the rest of Canada}

In 1989, the other (common-law) provinces of Canada had introduced the concept of equal division of the family property in their marital property laws for several years already (Appendix A Table A1). Before their reforms, the existing matrimonial regime, the "separation of property", ${ }^{16}$ implied that individuals kept their own property after divorce; however, the property accumulated during the marriage was frequently placed under the husband, who was usually the principal income earner in the family.

From Appendix A Table A1, we see that the basic idea of the equal sharing of family property is similar across provinces, even though the regulations in each province vary in details such as the right to share the family home, the concept of family property and the division of pre-marriage property. For example, even though the presumption of property division at divorce is equal distribution, the marital property law in Alberta does not specify how to share the family home directly and clearly. Additionally, Ontario and Newfoundland and Labrador laws describe how to share the family home in the case when the family home belongs to the pre-marriage property, but the other provinces do not. Ontario, Nova Scotia, Newfoundland and Labrador amended their marital property acts around 1989, and the others did not.

In order to conduct a treatment analysis in Quebec using a difference-in-difference model, we need to find a comparison group of provinces such that marital property laws have not been updated or replaced around 1989. As a result, Ontario, Nova Scotia, Newfoundland

to proxy for his/her ownership.

16 "Separation of property is the legal regime which now applies in all provinces, meaning that each spouse fully owns whatever he or she purchases. However, ownership is often uncertain over time or if a joint bank account served as the source of the purchase."(http://www.duhaime.org/LegalResources/FamilyLaw/ LawArticle-35/Matrimonial-Property-Law-in-Canada--A-Primer.aspx) 
and Labrador are excluded. We use the remaining six provinces as the control group since they have relatively similar marital property regulations ${ }^{17}$. The marital property law of these provinces defines the equal rights and responsibilities for each spouse. If the marriage ends, the family property will be divided in half along with the debts and liabilities. We can therefore compare the impact of the adoption of equal sharing of the marital property in Quebec on the labour supply comparing the changes before and after the 1989 amendment and differencing out the labour supply trends of the comparison group of provinces who had already adopted a system of equal division of the marital property.

\section{Data and Measurement}

The data used in this paper comes from the Labour Force Survey (LFS) over the period 1985-1995 ${ }^{18}$. The LFS is a representative monthly household survey that provides detailed information on individuals' labour supply and marital status as well as several additional demographic characteristics.

Table 1 presents the summary statistics of the basic characteristics of our sample (such as the proportion of all respondents in different marital statuses, the LFP rate, respondents' ages and education levels, etc.) for Quebec and the rest of Canada (with Ontario, Nova Scotia, Newfoundland and Labrador excluded), before and after the Civil Code amendment, separately. After comparing the summary statistics of these two groups in the pre-intervention periods, we can see that, on average, Quebec has a similar proportion of married/common-law couples and a slightly smaller proportion of divorced/separated people than other provinces. The proportion of single people is similar between these two groups. The average hours of work and the mean LFP rate in Quebec is slightly lower than those in other provinces. The proportion of female and respondents' age are on average very similar. Overall, we conclude that, before the Civil Code amendment, the Quebec sample shared attributes similar to those of the other provinces sample. Even though there are some differences, they are not large in magnitude. The similarity of observations' attributes between Quebec and the control group in the pre-intervention period suggests that the parallel trends assumption discussed later in this subsection, might be satisfied in our model.

We restrict our sample to women aged 18 to 65 years to capture as many observations

\footnotetext{
${ }^{17} \mathrm{We}$ also conducted a difference-in-difference analysis using all provinces except Quebec for the comparison group as a robustness check. The results, not reported here, are qualitatively similar to those that exclude Ontario, Nova Scotia, Newfoundland and Labrador.

${ }^{18}$ We drop observations referring to the period between July 1, 1989, and Dec 31, 1990. During this period, couples married prior the date (July 1, 1989) could choose whether the new family patrimony rules would apply to them. They had until December 31, 1990 to opt out of the amendment. Therefore, we exclude this period from our sample in order to avoid confounding effects coming from couples' decisions to review their marriage contract.
} 
with valid information on both labour supply and marital status as possible in the women's labour supply analysis. In contrast, for the analyses of individuals' marital decisions and of potential assortative matching, we restrict our sample to individuals aged 18 years and above to ensure all respondents had reached the legally marriageable age. In these three analyses, we have imposed further conditions, described in Section 4, on our sample to better investigate our research questions.

For the measures of labour supply outcomes, we use women's labour force participation and the usual number of hours worked per week with the cross-sectional format of the LFS. To analyze the impact of the law change on divorce, we exploit the longitudinal 6-month panel format of the LFS data to create monthly marital status transitions. Additionally, to analyze the potential assortative matching implications of the Quebec amendment, we use differences in educational attainment between spouses as our main interest by following the existing studies (Mare (1991); Kalmijn (1994); Pencavel (1998); Watson et al. (2004)) since individuals' education decisions are more likely took place before the law change. Moreover, peoples' education attainments are related to their earnings. Employing this measure as our outcome of interest allows us to explore whether the reforms induced people to marry a partner with similar financial status.

It should also be noted that the family patrimony rules in Quebec apply only to married couples, not common-law unions. However, the marital status question in the LFS does not distinguish the two groups in the years studied. We will present robustness checks the estimations using alternative data coming from the Census in which married and common law couples are separately identified.

Table B1 in Appendix B presents the difference-in-difference framework for the married women's labour-force analysis, and describes the treatment group (T) and control groups (C).

In difference-in-differences identification strategies, a parallel-trend assumption is required for consistency. Figure 1 and Figure 2 present the average hours of work and the labour force participation rate, respectively, of the women in the treatment group (women married/cohabited before 1989 in Quebec) and the control group (women married/cohabited before 1989 in the other provinces) from 1985 to 1995. From each graph, an upward trend can be seen in both the treatment and control groups, while the hours of work and labour force participation rate are higher in the control group. After comparing the trends in the outcome of interest between these two groups in the pre-intervention periods (LFS, 1985-1989), we might suggest that the parallel trend assumption appears to be satisfied. In addition, we also use Equation 1 to test whether the treatment and control groups have common trends in the pre-policy periods. 
Figure 1: Hours of Work among married Women, 1985-1995

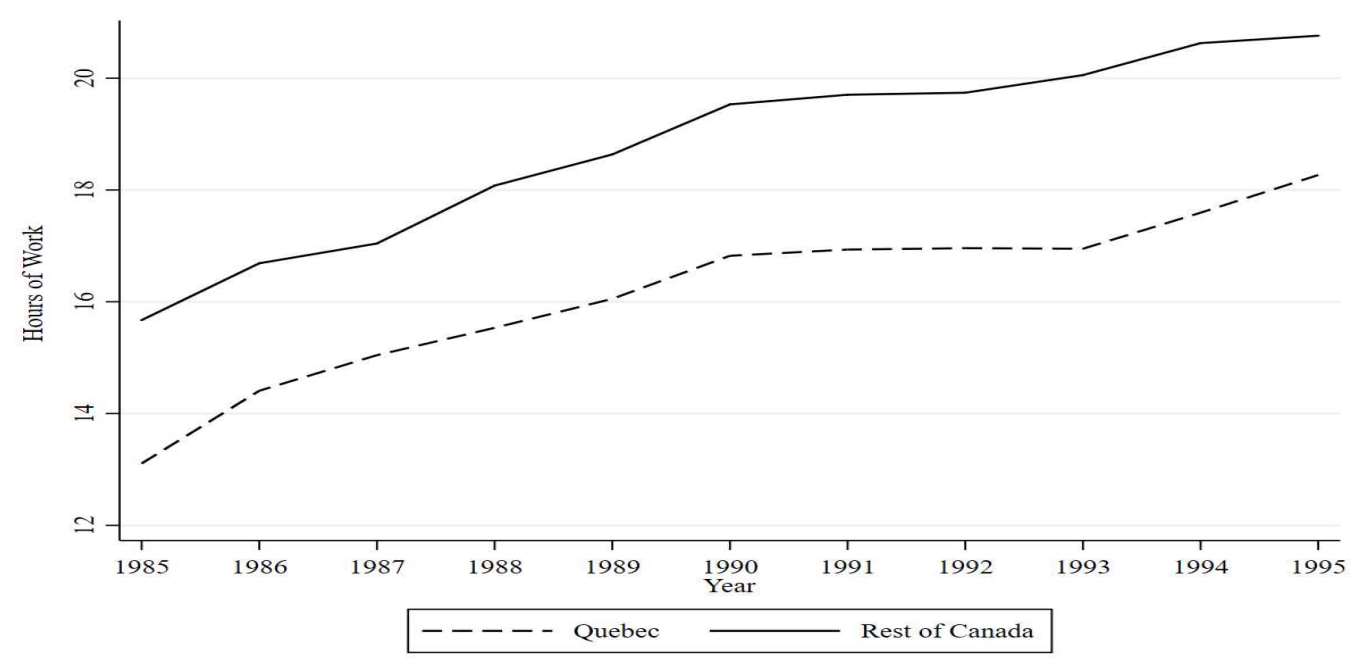

Figure 2: Labour Force Participation Rate among married Women, 1985-1995

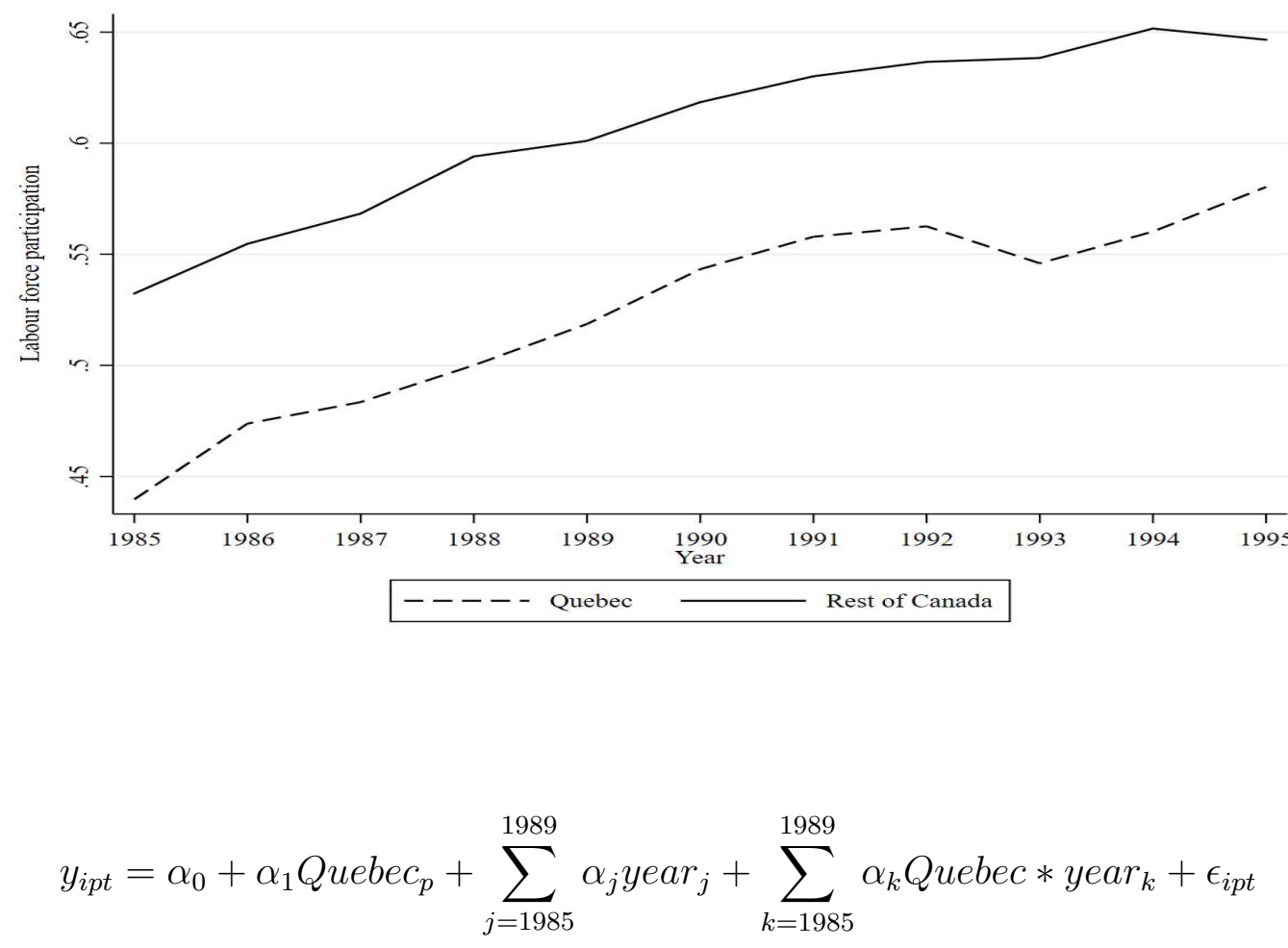

We test the hypothesis that the coefficients of $Q u e b e c * y_{e a r_{k}}$ are equal to each other (Test results are reported in Table B2 of Appendix B). The coefficients of Quebec * year ${ }_{k}$, which indicate the potential anticipated effects among women in Quebec before the policy changes, are statistically insignificant suggesting evidence of parallel trends. 


\section{Analysis}

\subsection{Impact of the Quebec Family Patrimony Rules on Married Women's Labour Supply}

In this section, we are interested in analyzing the impact of the Quebec family patrimony rules on wives' labour market behaviour. We use the changes in the family patrimony rules in Quebec as the treatment and the population of married women as the population susceptible to respond to the treatment and apply a difference-in-difference identification method using group of married wives in other provinces which did not experience changes in family patrimony rules over that time period as the control group.

In 1970, Quebec experienced a change in its matrimonial regime. For couples who married before July 1, 1970, the "community of property" was the default regime. After that date, the default regime became the "partnership of acquests". However, the "community of property" regime can still be chosen by couples today in a marriage contract. To insure that our sample of wives faced the same default regime at marriage throughout the sample period, we need to exclude couples whose matrimonial regime is the "community of property". Based on 1985 data from Quebec statistics, only $0.06 \%$ of couples were under the "community of property" regime. This suggest that the exclusion of the couples under this regime is not a major sample selection concern.

More importantly for our analysis of the labour market response of married women before and after the 1989 law changes, we need to insure that our sample faced the same matrimonial property laws at marriage which implies that they all married before the 1989 law change.

\subsubsection{Sample}

The choice of sample is based on information regarding the duration or the year of the respondent's marriage. Identifying couples who married before 1989 for the pre-intervention periods (LES, 1985-1989) is straightforward. For instance, if a respondent's status is indicated as "married" in these survey years, he/she automatically matches the rule of being married before 1989. However, selecting couples married before 1989 for the postintervention periods is tricky without information on the year of the marriage or marriage duration. The 6-month panel format of the LFS is too short and cannot be used to estimate marriage duration. We proxy for duration by using information on the age of the couples' children or the wife's age of the couple has no children. The first child of a couple who married before 1989 will be five years of age or above by the time of the post-intervention 
survey years of 1991 and $1995^{192021}$.

For wives without children, we calculated the average age of women without children who married before 1989 using the information from the General Social Survey (GSS), Cycle 5, 1990 and Cycle 10, 1995 because these two cycles of the GSS provide abundant details of respondents' marriages including age at marriage. Using wives' ages at marriage and their current age, we are able to figure out the date of their marriages and then select those who were married between 1970 and 1989 and have no children in their family. Based on this group of women, we calculated an average age of 40 in Cycle 5, 1990, and 51 in Cycle 10, 1995 22 . Therefore, we select wives without children aged more than 40 years for all post-intervention years. We also impose this restriction on all pre-intervention years to keep the pre-intervention and post-intervention samples as similar as possible. This age restriction also allows to exclude the group of married women who might be influenced by the amendment of the social assistance policy which took place in Quebec in 1989. This amendment improved the benefit of childless social assistance for individuals under 30 years who have no children living with them, which further affected their labour market behaviour (Lemieux and Milligan (2008)).

Our sample selection strategy serves an additional purpose which is to further identify the population most likely to be impacted by the treatment reflected in the 1989 Act. Because divorce risk declines over the course of a marriage (see Simard-Duplain (2018) for a detailed structural analysis of the dynamics of marital and labour supply decisions over the life cycle), a divorce reform may have weaker effects on more mature married couples who have optimized their choices of labour supply and marital status. However, the 1989 Civil Code amendment reflected an unexpected change in the redistributive divorce law and as a result, created a transitory (one-time change) and unanticipated wealth change which

\footnotetext{
${ }^{19}$ Note that this approximation (age of the first child) is only suitable for women in their first marriages. Women in the second or third marriages could have children from previous relationships. Therefore, the age of the first child cannot approximate the duration of the current marriages. On the other hand, according to the General Social Survey (GSS), Cycle 5, 1990, 89.49\% of married women aged 40 years and above (an age group who are more likely to have children five years of age or above) are in their first marriages. Note also that children could be born when parents are living in common-law (prior to marriage). However, according to the GSS, Cycle 5, 1990, the proportion of women having children prior to their first marriages is only $7.38 \%$. In order to further improve the precision of our estimations, an alternative approach will be discussed in Section 5.

${ }^{20}$ The retrospective nature of the GSS data allows us to distinguish whether a respondent's current marriage is his/her first as well as obtain his/her duration of marriage. However, we do not use this dataset in our study for two reasons. First, the small sample size of the GSS is a main limitation of conducting our research using the difference-in-difference method when the treatment group only focuses on a specific group of women in Quebec. Second, the potential recall bias problem of using the retrospective data has been addressed by many researchers (Horvath (1982); Sable (1999); Paull (2002)).

${ }^{21}$ We use measures that indicate the number of children in a specific age group in the LFS (e.g., the number of children between 0 to 5 years, the number of children between 6 to 14 years) to capture the age of first children in the household.

${ }^{22}$ Some women without children in 1990 may give birth in the next five years and exist from this group. Thus, the average age of this group in 1995 is higher than expected.
} 
is expected to generate a labour supply response through a leisure-inducing income effect and the response is also expected to be stronger for older spouses who have accumulated assets.

\subsubsection{Specification and Estimation}

To estimate the effect of the family patrimony rules on the married women's labour supply, the difference-in-difference specification of this analysis is:

$$
y_{i p t}=\alpha_{0}+\alpha_{1} \text { After }_{t}+\alpha_{2} T_{i p}+\alpha_{3} T_{i p} * \text { After }_{t}+\sum_{n} \beta_{n} X_{i p t}+\delta_{t}+f_{p}+c_{p t}+\mu_{i p t}
$$

where $y_{i p t}$ is either the number of hours worked by women or women's labour force participation. After $r_{t}$ is the post-intervention periods' indicator, which is equal to 0 for survey years 1985-1989, and 1 for survey years 1991-1995. $T_{i p}$ is the treatment group indicator. Therefore, our main interest, $\alpha_{3}$, indicates the responsiveness of married women's labour market behaviour to Quebec's family patrimony rules. $X_{i p t}$ is a group of control variables: age dummies, whether they have children or not, whether they have children under five years, whether they have a high school degree or less, and the age of their first children dummies $^{23}$. We also include province fixed effects $\left(f_{p}\right)$, year-by-month fixed effects $\left(\delta_{t}\right)$, and province-by-time fixed effects or province-specific time trends $\left(c_{p t}\right)$ in our model to control for some provincial and nation-wide changes, as well as the differential trends of female labour force participation. ${ }^{24}$ The standard errors $\left(\mu_{i p t}\right)$ are clustered at the province-by-time level (Bertrand et al. (2004)) $)^{2526}$.

At the extensive margin, we apply the linear probability model (LPM) as our baseline estimation. We also employed the Logit estimation as a robustness check. At the intensive margin, we use the OLS estimation as our baseline model. In our sample, a fairly large proportion of married women worked zero weekly hours (they are either out of the labour force or unemployed). Thus, we use the Tobit and Heckman models as a robustness check (Heckman (1977)). Additionally, we estimate the impact of the family patrimony rules on married women's hours of work using unconditional quantile (UQ) regression following

\footnotetext{
${ }^{23}$ Including the age of their first children dummies can help us to control differential marriage/relationship duration among married women.

${ }^{24}$ The results are similar whether or not we include province-speficic time trends.

${ }^{25} 798$ clusters: 7 provinces times 10 years times 11.4 months (The observations between July 1, 1989, and Dec 31, 1990, have been dropped.).

${ }^{26}$ Researchers have questioned the correlation across clusters of clustering on province-year pair (Cameron and Miller (2015)). Therefore, we estimate the standard errors clustered at different levels (cma-by-time and province-by-cluster). While the results are not shown to avoid lengthening the appendix (but available upon author's request), we find that the level of statistical significance of the results do not change across the various clustering methods. We also performed the two-step method developed by Donald and Lang (2007) as an additional robustness check and the results were also very similar.
} 
Firpo et al. (2009) $)^{27}$ We explore the effects of Quebec's family patrimony rules on hours of work per week for three different samples of married women according to the strength of their attachment to the labour force. First, we focus on the sample of all married women, which is the one used at the extensive margin (follow Angrist and Pischke (2009)). Second, the sample is restricted to married women who are in the labour force, either employed or unemployed and more strongly attached to the labour force compared to the women in the first group. Third, we further restrict the sample to married women who have been employed 6 years or more (to insure they were employed before the policy changes and stayed employed afterwards). This group of women has the strongest attachment to the labour force. Estimating the impact of the family patrimony law change over this group of women who were employed before the law change remained employed throughout the period helps isolate the intensive margin response and eliminates any compositional effects coming from a change in married women labour force participation before and after the law change.

\subsubsection{Results}

Table 2 indicates the treatment effects on married women's labour supply using Equation 2 at both the intensive and extensive margins. A full set of control variables described in Section 4.1 is included in each specification. ${ }^{28}$

At the intensive margin (rows 1-3), the OLS estimations (column 1) imply that the labour supply of married women in Quebec (subject to the family patrimony law change) has declined by 0.43 hours per week (not statistically significant) compared to those in the other provinces. When we restrict our sample to married women in the labour force, as expected, this negative effect of the Civil Code reforms in Quebec on wives' work hours is stronger and significant. The estimated reduction in labour supply is 1.42 hours per week. Furthermore, when the sample is restricted to married women who were employed before and after the policy changes, the labour supply reduces by 0.70 hours per week significantly among this group of women. The magnitude of the hours adjustment is smaller among employed women with longer tenure.

The results of the Tobit (column 2) and Heckman regression (column 3) estimations are consistent with those in the OLS estimation. The UQ estimates (column 4) also indicate that, at the median, the impact of the Civil Code reforms in Quebec on wives' hours worked is strongest when we restrict our sample to married women in the labour force.

\footnotetext{
${ }^{27}$ We used the Stata programs generously shared by their authors on Nicole Fortin's webpage at faculty.arts.ubc.ca/nfortin/datahead.html. The UQ approach has been used previously to analyze labour supply effects of policy changes in Schirle (2015) and Koebel and Schirle (2016).

${ }^{28}$ In the Heckman selection model, we use spouse's education as the additional variable in the selection equation.
} 
At the extensive margin (row 4), the results from the LPM estimation (column 1) and the Logit model (column 2) show that the family patrimony rules had no statistically significant effect on the probability of married women entering the labour force.

In summary, we find a statistically significant negative effect of the Civil Code reforms in Quebec on wives' working hours and the impact is consistent with the prediction of the collective model by Chiappori et al. (2002), which indicates that women will reduce their labour supply when the intra-household bargaining power shifts to their benefit.

\subsubsection{Robustness Checks}

As mentioned earlier, the family patrimony rules in Quebec apply only to married couples, not common-law unions but the marital status question in the LFS data does not identify separately couples who are married from those who are cohabiting. Since spillover effects of the Quebec marital property law change on cohabiting couples are possible, the labour supply effects of the law change we find could be driven by the women living in common-law unions. A few studies noted that the incidence of common-law unions is substantially higher in Quebec than in the rest of Canada (Statistics Canada (1997); Le Bourdais and LapierreAdamcyk (2004)). In appendix C.1, we present summary statistics from the Census data for the years 1981, 1986, 1991 and 1996 based on the same sample selection rules as those we used with the LFS data for comparison. The demographic characteristics are similar between the two datasets. We note as well the relatively higher rate of common-law unions in Quebec compared to other provinces.

We performed a difference-in-difference analysis using the Census data and estimating separately the impact of the Quebec marital property law change for married and commonlaw unions. The results however (not included but available upon authors' request) were inconclusive because of the fact that having two data points for the pre-intervention period does not generate sufficient variations to allow precise and meaningful estimations. ${ }^{29}$

On the other hand, if we calculate the trends in the incidence of common-law unions and compare the pre-intervention and post-intervention periods (Appendix C.1 Table C2), we see that the within trends in Quebec and the rest of Canada have evolved in a remarkably similar way. The rates increased by $2.62 \mathrm{ppt}$ in Quebec and $0.51 \mathrm{ppt}$ in the rest of Canada before 1989 and increased by 2.96 ppt in Quebec and 0.87 ppt in the rest of Canada over the 1991-1996 time period. In both cases, the trends have increased by about the same quantity (0.3 ppt) before and after the 1989 marital property law change. We therefore do

\footnotetext{
${ }^{29}$ The results showed estimates of the effect of the Quebec law change for both married and common-law union women that were of larger magnitude and with standard errors that were four to five times larger than the magnitude of the estimated standard errors based on the LFS data. This may not be surprising as small variations in the covariates create a large inverse matrix X'X affecting simultaneously both the magnitude of the estimated betas and their standard errors.
} 
not observe a relatively greater change in the common-law trends in Quebec compare to other the provinces around the year of the law change.

Furthermore, we performed an event study using the LFS data by estimating the impact of the marital property law change at the different post-intervention years. The results (presented in Appendix C.1 Table C3) show that the estimated effects of the law change on the labour supply of married women are strong and statistically significant only in the first two years following the law change, a time period during which the incidence rate of common-law unions was not growing particularly more strongly in Quebec compared to the rest of Canada (from our previous trends analysis).

Overall these additional results suggest that the labour supply impacts found in Table 2 using the LFS data are unlikely to be driven by a change in the relatively greater incidence of common-law unions in Quebec compared to the rest of Canada.

Another concern relates to the possibility that other policy changes occurred in Quebec around 1989 that may have impacted the labour supply of married women. In particular, in the May 1988 budget, the Quebec government introduced a baby bonus called the Allowance for Newborn Children (ANC) under the Act Respecting Family Assistance Allowances (Milligan (2002)). ${ }^{30}$. Moreoever, in September 1989, the Quebec government announced its intention to provide 27 weeks of paid leave (in addition to the 15 weeks covered by federal maternity benefits) to parents who have three or more children and grant 34 weeks of unpaid paid parental leave (Baker (1994)). Since these family policies potentially affected the fertility decisions of all families with and without children, our analysis needs to control for the presence of a newborn in addition to controlling for the couples' number of children. Appendix C.2 Table C4 shows the results of estimations replicating the analysis done to produce the results of Table 2 but adding an additional control for the presence of a newborn. The results are very similar whether or not we control for the fact that women may have responded to the baby bonus and extended parental leave incentives.

Also, new income and employment support programs were introduced in Quebec in 1988 and 1989 (Seguin (1998)). The programs targeted families with a spouse with a mental or physical condition limiting employment (See Canada, 1988. Bill S-3.1.1. for a description of the financial support program), or low-income families with at least one dependent child (See Canada, 1988. Bill S-3.1.1. as well for a description of the parental wage assistance program). To be eligible for the first program, one spouse has to be incapacitated and unable to work. To be eligible for the second wage assistance program, the family cannot own a property. We reran our estimations separately for the sample of married women who would not qualify to any of these two programs. In the first case, the estimations were done

\footnotetext{
${ }^{30}$ Payments under the ANC took the following form. Initially, families received $\$ 500$ on the birth of their first child, $\$ 500$ for a second child, and the first of eight quarterly payments of $\$ 375$ (totalling $\$ 3,000$ ) when a third or subsequent child joined the household. By 1992, the benefit grew to $\$ 500$ for a first child, $\$ 1,000$ for a second, and 20 quarterly payments of $\$ 400$ (totalling $\$ 8,000$ ) for a third or subsequent child.
} 
over the sample of married women with an employed husband (Appendix C.2 Table C5) and in the second case, over the sample of married women of families who indicate being home owners (Appendix C.2 Table C6). ${ }^{31}$ In both cases, the results are very similar to our main results in Table 2. We conclude that the labour supply effects found in Table 2 are not driven by the financial support or the parental wage assistance programs.

An additional way to test for the validity of our difference-in-difference model is to perform a falsification test. Since the Civil Code reform was designed for married couples, single people in Quebec are unlikely to have been affected by the change in family patrimony rules. We can therefore impose a "false" treatment in 1989 for single women in Quebec. The identification, estimation method and results of this analysis are presented in Appendix C.2. As expected, the results reported in Appendix C.2 Table C7 show that single women in Quebec did not respond to the family patrimony rules, since the results are statistically insignificant.

\subsubsection{Heterogeneous Effects}

Next, we further explore the effects of the Quebec law change by considering possible factors by which the law change affected intra-household bargaining power: the potential returns to the wife's investments in the labour market, as well as its interaction with the accumulated property wealth (the size of the pie to be equally divided in the event of a divorce). We estimate the wife's potential returns to labour market investments using her education level. We proxy for the magnitude of the wealth associated with the property by using information on her household's property ownership.

Table 3 shows the impact of the family patrimony rules further interacted by the wife's highest level of education achieved (HSLess is equal to 1 if wives have a high school education or less, and equal to 0 if wives have post-secondary education) The difference-in-difference specification equation for this analysis is:

$$
\begin{gathered}
y_{i p t}=\alpha_{0}+\alpha_{1} \text { After }_{t}+\alpha_{2} T_{i p}+\alpha_{3} T_{i p} * \text { After }_{t}+\alpha_{4} \text { HSLess }_{i}+\alpha_{5} T_{i p} * \text { HSLess }_{i} \\
+\alpha_{6} \text { After }_{t} * \text { HSLess }_{i}+\alpha_{7} T_{i p} * \text { After }_{t} * \text { HSLess }_{i}+\sum_{n} \beta_{n} X_{i p t}+\delta_{t}+f_{p}+c_{p t}+\mu_{i p t}
\end{gathered}
$$

In this case, $\alpha_{3}$ indicates the potential impact of the family patrimony rules on wives' labour market behaviour who are more-educated, while the sum of $\alpha_{3}$ and $\alpha_{7}$ indicates the potential impact among less-educated wives. $\alpha_{7}$ presents the differential impact between these two groups.

\footnotetext{
${ }^{31}$ The results based on home renters are not included because the sample size drop was too large for the results to provide any additional useful information.
} 
At the intensive margin, the results among all married women (rows 1-2), indicate that the decline of women's labour supply due to the Quebec reform found in Table 2 seems to be mainly driven by the more-educated wives. For instance, as mentioned, the effect for more-educated wives in Quebec is represented by the coefficient of $T_{i p} *$ After . The effect for less-educated wives is given by the sum of the coefficients for $T_{i p} *$ After $r_{t}$ and $T_{i p} *$ After $_{t} *$ HSLess $_{i}$. In the OLS model (columns 1-2), the sum is $-1.05+0.71=-0.34$ and statistically insignificant (SE 0.31), while the coefficient of $T_{i p} *$ After $t_{t}$ is negative and significant. The Tobit (columns 3-4) and Heckman (columns 5-6) estimates are qualitatively similar to the OLS estimates. In addition, the UQ estimation (columns 7-8) indicates consistent and stronger results at the median than those obtained with the OLS. This could be the case because a greater proportion of less-educated wives may not be working and have no hours of work to adjust down from ${ }^{32}$.

Among married women who are more strongly attached to the labour force (rows 3-6), the results indicate that the decline in working hours is mainly driven by the less-educated wives, consistent with the idea that the law change provided more bargaining power to the group of women who had the least of it prior to the change. Given the lower returns from the labour market for less-educated wives, an equal division of the family property would be relatively more attractive financially compared to more-educated working wives whose potential earnings are greater. In fact, this impact is expected to be stronger, the larger the size of the property wealth to divide. We analyze this hypothesis in the next table.

At the extensive margin (rows 7-8), we see that more-educated wives are significantly more likely to exit the labour force, while less-educated wives are more likely to join the labour force. For instance, the effect for less-educated wives is $-0.02+0.04=0.02$ and statistically significant from 0 (SE 0.01) in the OLS model. The Logit estimates are qualitatively similar to the OLS estimates. This result showing opposite effects of the law change by wives' education level at the extensive margin is surprising. This finding may result from the endogenous joint labour market decisions of couples who stayed married after the law change (Manser and Brown (1980); McElroy and Horney (1981); and Goussé et al. (2017)). A more-educated working wife who has likely already contributed substantially to the household public good during the marriage may be able to convince her husband to agree on letting her allocate more time to her own leisure as a result of the increased share of the household wealth than a less educated wife who has not been able to contribute as much.

We are also able to further test whether the differential impact of the law change by education is driven by the size of the assets to be divided at divorce with house owners having a relatively larger pie to divide than house renters. Table 4 summarizes the results from estimating the effects of Quebec's family patrimony rules on married women's labour

\footnotetext{
${ }^{32}$ In the sample, less-educated married women have median hours of work of 0 .
} 
supply by education among house owners. At the intensive margin (rows 1-6), we see that, as expected, the decline in labour hours supplied due to the reform is similar and slightly stronger (except the UQ regression) compared to the results in Table 3.

At the extensive margin (rows 7-8), we see that more-educated wives whose household owns a house are more likely to leave the labour force, as before. As mentioned, moreeducated women who have probably already contributed substantially to the household public good, especially to assets as major as a house, are more likely to be able to convince their husband to drop out of the labour force and allocate more time to leisure. This type of negotiation regarding dropping out of the labour force may be less successful in couples where the wife is less educated and with lower earnings. Unlike the results shown in Table 3, less-educated women in a household who owns a house did not statistically significantly respond to the reform in this case. For instance, the effect for less-educated wives is $-0.03+0.04=0.01$ and statistically insignificant (SE 0.01) in the OLS model. The Logit estimates are qualitatively similar with that in the OLS.

Couples who rent a house might be unlikely to have been affected significantly by the equal division of the family property since a house usually represents the major family asset. However, the changes in family patrimony rules can influence their labour market behaviour through redistributing the pension in the event of a divorce. We further analyze the family patrimony rules effects among house renters by husbands' education as the husband is usually the principal earner in the household (Gray (1998); Chiappori et al. (2002); Stevenson (2008)). Their education level, which is related to the potential returns to labour market investments, could be a proxy for the magnitude of the pension to be equally divided in the event of a divorce.

We report coefficient estimates rather than marginal effect given the problems of calculating and interpreting the marginal effect of an interaction term in a nonlinear model have been discussed in many studies (Athey and Imbens (2006); Lechner et al. (2011); Buis et al. (2010); Puhani (2012); Karaca-Mandic et al. (2012)). As the authors point out, calculating the first derivative of the interaction term as the marginal effect can lead to a biased result when using a difference-in-difference approach(Buis et al. (2010)). Puhani (2012) and Buis et al. (2010) provide an alternative way to calculate the interaction effect and some tips of interpreting it, respectively.

A concern is that our post-policy sample is not randomly selected since the Civil Code reforms may affect individuals' marital decisions (e.g., likelihood of divorce). For instance, we have selected women who stayed married in the post-policy sample excluding from the analysis the possible impact of the law change on the labour supply of women who divorced as a result of the amendment. The Civil Code reforms in Quebec, by changing the intrahousehold bargaining positions of each spouse, may have encouraged divorce for people who wanted to prior to the law but could not afford to. In this case, wives who married 
before the law change and decided to stay married afterwards may have different labour supply response than those whose marriages did not survive. This fact may influence our estimations through introducing a selection bias in the results. We investigate this issue in the next section when we analyze whether the family patrimony rules affect marital decisions.

Evidence that the Quebec family patrimony rules impacted divorce rates will indicate that while the labour supply response we have estimated is conditional on staying married, ignoring the labour supply response associated with divorce can only provide a lower bound to the overall short-run female labour supply response coming from the law change. ${ }^{33}$

Note also that given our results in Table 3, if more education provides married women with the bargaining power to drop the labour force while staying married, it is possible and we suspect that education may also moderate the impact of the Quebec redistributive law change on divorce rates. The less educated spouse, being the one most likely to benefit from equal sharing of the family patrimony may be more likely to divorce after the law change relative to the more educated spouse. We therefore also investigate this potential differential effect by education in the next section.

\subsection{Impact of the Quebec Family Patrimony Rules on Divorce Transitions and Assortative Matching}

\subsubsection{Impact on Divorce Transitions}

In this section, we want to further explore whether the Quebec family patrimony rules affected individuals' divorce decisions. In order to analyze the dynamics of divorce, we use the 6-month panel format of the LFS 1985-1995 and select both women and men aged 18 years and above who were already married when they were first surveyed, and then follow their marital status over the 6 survey months to identify a change in marital status by the end of the 6-month period. We define our dependent variable indicating the transition from married to divorce (or separation) as a dummy variable equal to 1, if a person reports being divorced/separated sometime during the second to 6th month, and 0 if the person stayed married during the 6-month window. Table B3 in Appendix B presents the difference-indifference framework for divorce transitions, and describes the treatment group (T) and control group (C).

The parallel trend test results (reported in Table B2 of Appendix B) using Equation 1 (where $y_{\text {ipt }}$ is a dummy variable of 1 , reflecting a person divorce/separation, or 0 , reflecting

\footnotetext{
${ }^{33}$ Abstracting from the changes in the patrimony rules, the labour supply of divorced women is generally greater than the labour supply of married women with a working spouse. Our results for married women are therefore likely to suffer from a downward bias given that divorced women with generally greater labour supply are excluded from the sample. We will return to this discussion point in the next section.
} 
staying married over the 6-month window) allow us to not reject the null hypothesis that the coefficients of $Q u e b e c * y_{e} r_{k}$ are equal to each other ${ }^{34}$. Additionally, all the coefficients of $Q u e b e c *$ year $_{k}$ are statistically insignificant, which implies that no effect was anticipated among people in Quebec in response to the 1989 Act.

To estimate the treatment effect on individuals' divorce transitions, we use Equation 2 to regress the dummy variable that reflects whether an individual gets divorced or stays married using the Logit estimation. Additionally, the impact of the family patrimony rules on individuals' divorce transitions may differ depending on their own and spouses' education. For instance, a relatively less-educated spouse who is less likely to accumulate the majority of family assets during the marriage might take advantage of the relatively more-educated spouse due to the equal division of the family property. This possibility might have encouraged divorce for people who are less-educated than the spouse and wanted to divorce prior to the law but could not afford to. Therefore, we further extend this analysis depending on whether a respondent is less, or more than, or equally educated to the spouse, using Equation 4 with the Logit estimation. $\alpha_{3}$ indicates the potential impact of the Quebec family patrimony rules on divorce decisions of respondents who have the same education as their spouses, while the sum of $\alpha_{3}$ and $\alpha_{6}$ indicates the potential impact of respondents who are less educated than their spouses, and the sum of $\alpha_{3}$ and $\alpha_{7}$ indicates the potential impact of respondents who are more educated than their spouses.

$$
\begin{aligned}
& y_{i p t}=\alpha_{0}+\alpha_{1} \text { After }_{t}+\alpha_{2} \text { Quebec }_{i p}+\alpha_{3} \text { Quebec }_{i p} * \text { After }_{t}+\alpha_{4} \text { less }_{i}+\alpha_{5} \text { more }_{i} \\
& +\alpha_{6} \text { Quebec }_{i p} * \text { After }_{t} * \text { less }_{i}+\alpha_{7} \text { Quebec }_{i p} * \text { After }_{t} * \text { more }_{i} \\
& +\sum_{n} \beta_{n} X_{i p t}+\delta_{t}+f_{p}+c_{p t}+\gamma_{i p t}
\end{aligned}
$$

Table 5 (Column 1) presents the effect of the Quebec family patrimony rules on individuals' divorce decisions regardless of the differential education between spouses. The results provide little evidence that these rules affect couples' divorce decisions. However, once the differential education between spouses is taken into account, the results in this table (Columns 2-4) suggest that, as initially speculated, it is the less educated spouse who is more likely to get divorced/separated. For instance, the potential impact on divorce of individuals who are less educated than their spouse, calculated by the sum of the coefficients of Quebec $_{i p} *$ After $_{t}$ and Quebec $_{i p} *$ After $_{t} *$ less $_{i}$, is $0.79+0.40=1.19$ and statistically significant (SE 0.63). In contrast, the potential impact of individuals who are more educated than their spouses, calculated by the sum of the coefficients of Quebec $_{i p} *$ After and $_{t}$ Quebec $_{i p} *$ After $_{t} *$ more $_{i}$, is $0.79-0.22=0.57$ and insignificant (SE 0.52). The potential

\footnotetext{
${ }^{34}$ We use the cross-sectional format of the LFS to perform the parallel trend test due to the small size of people getting divorced/separated within a 6-month window in the panel format.
} 
impact of individuals who are equally educated as their spouses, indicated by the coefficient of Quebec $_{i p} *$ After $_{t}$, is insignificant as well.

These results on the impact of the change in family patrimony rules on divorce by education are consistent with our findings in the previous section and help us provide a more complete interpretation of the impact of the redistributive law change on married women's labour supply. By reinforcing the bargaining power of the least advantaged spouse in the marriage, the redistributive law change lead to a decline in hours worked stronger for the less educated married women. At the same time, since it is the group of the less educated men and women who is also more likely to divorce to take advantage of the equal sharing rule, the estimated hours decline we find among the sample of married women (excluding women who divorced after the amendment) corresponds to a lower bound of the labour supply response. The overall labour supply response, including married and divorced women would have created an even greater hours decline associated with the law change.

\subsubsection{Assortative Matching}

The changes in the Quebec family patrimony rules may also affect individuals' decisions of whom to marry. Due to the equal share of family property in the event of a divorce, people who marry after 1989 are more likely to look for a partner with equal financial background relative to before 1989. This probably occurs because couples with similar economic backgrounds are more likely to make equal contributions during the marriage than those who have unequal backgrounds, which makes the equal share of family property at divorce more fair and reasonable.

For this question, we mainly focus on differential educational attainment between spouses since individuals' education level approximates well earnings potential and using current earnings creates endogeneity problems. We note that the education trends have been similar in every provinces in Canada. Table 6 presents the proportion of individuals with high school education or less in Quebec and the rest of Canada by gender in both pre and post intervention periods. The proportion has declined after 1989 as both men and women are getting more educated after the Civil Code reform. Moreover, the change in the proportion before and after the reform is of similar magnitude for each gender as well as similarly in Quebec and the rest of Canada. Any results we find cannot therefore be driven by the differential in educational attainment between Quebec and the rest of Canada prior to 1989 or the gender differential in educational attainment.

For this analysis, we select couples whose decision to marry took place either before or after 1989. We use individuals' age to approximate whether they got married after 1989 or not. For instance, we assume that young couples aged 30 years or less are more likely to have 
married after $1989^{35}$. This restriction (age $\leq 30$ ) is also imposed on couples married before 1989 to ensure similarity of the attributes between pre-intervention and post-intervention samples. Additionally, this age restriction helps us to insure that couples' current marriages/relationships are their first unions. Second, we calculate the differential educational attainment between spouses and compare this difference between couples married before and after 1989 in Quebec relative to the other provinces, using a difference-in-difference approach. Table 7 presents how we derive the differential educational attainment between spouses, which has three values, -1, 0, or 1. Table B4 in Appendix B presents the differencein-difference framework for the assortative matching analysis, and describes the treatment group (T) and control group (C).

Regarding the parallel trend assumption, according to the parallel trend test results (reported in Table B2 of Appendix B) using Equation 1 (where $y_{i p t}$ is the differential education between spouses), we cannot reject the null hypothesis that the coefficients of Quebec*year ${ }_{k}$ are equal to each other.

Table 8 presents the treatment effect using Equation 2. ${ }^{36}$ We carry out separate analyses based on three different base outcomes (when the differential educational attainment $=0$ ): both spouses have a high school education or less, both spouses have more than high school education, and pool these two cases together as the base outcome. The coefficients of $T_{i p} *$ After ${ }_{t}$ based on the first and third base outcomes suggest that, among young couples (age $\leq 30$ ) in Quebec, the equal share of family property in the event of a divorce has contributed to a greater likelihood of unions in which the wife is more educated than the husband; similarly, the results based on the second base outcome imply that the Quebec marital property change contributed to a lower likelihood of unions in which the wife are less educated than the husband. ${ }^{37}$

\section{Conclusions}

In this study we examine the impact of an amendment of the Quebec Civil Code towards greater economic equality between spouses on married women's labour supply and on divorce decisions and the decision of whom to marry. We exploit detailed information on individuals' labour market and marital status from the Labour Force Survey to analyze short-run changes in outcomes before and after the reform in Quebec relative to other provinces which did not experience marital property law changes over that time period.

Consistent with the prediction of the bargaining model of marital decisions (Chiappori

\footnotetext{
${ }^{35}$ At least one of the spouses was 30 years or less.

${ }^{36} T$ is Quebec dummy in this case and there is no demographic control variables $X_{i p t}$.

${ }^{37} \mathrm{We}$ also used a measure of the differential age between spouses. However, the results, not reported, were statistically insignificant likely because the age restriction (age $\leq 30)$ imposed in the analysis has removed most of the variations in the sample.
} 
et al. (2002)), family patrimony rules that improve economic equality between spouses reduce married women's hours of work. We estimate a decline of about 22 hours per year. This effect is larger among married women with stronger attachment to the labour force. The estimated decline in hours for the group of women employed before the law change is 36 hours per year. In addition, we also find that the adverse employment effect of the Quebec changes in family patrimony rules is relatively stronger for less educated women (the most disadvantaged spouse) and among couples with larger wealth as measured by the ownership of the couples' property.

At the extensive margin, we find that the redistributive law change significantly decreased the labour force participation of the relatively more educated married women but increased the labour force participation of the relatively less educated women (among married women who stayed married). This differential result by education among married women suggests that the labour supply impact of the redistributive law change likely depends on the decision to stay married as marital decisions are also part of the household bargaining outcome. We investigate this question by studying the Quebec amendment impact on divorce rates and the decisions of whom to marry.

We find that the redistributive law change had no impact on overall divorce but significantly increased the likelihood of divorce/separations among less educated spouses. In addition, over the sample of young individuals deciding whether or not to marry, the Civil Code amendment contributed to increasing the proportion of marriages in which the wife is more educated than the husband.

Together these results suggest that family reforms with the goal of promoting economic equality between spouses in the long-run, may create unintended short-run vulnerabilities. Indeed, our results show that the redistributive law change lead the less educated married women to reduce their working hours. Married women who are more educated and are therefore relatively less disadvantaged are also more likely to drop the labour force as a result of the law change. Furthermore, the less educated spouse is more likely to divorce as a result of the law change; marriage, an institution that provides insurance against poverty, is more likely to take place among couples where the woman is relatively more educated than the man. At the same time, these results also suggest that education remains a key element to alleviate poverty and help reinforce the effectiveness of complementary family reforms. 
Table 1: Summary Statistics of Respondents' Basic Characteristics in Quebec and Other Provinces in Pre and Post Intervention Years

\begin{tabular}{|c|c|c|c|c|c|c|c|c|}
\hline & \multicolumn{4}{|c|}{ Quebec } & \multicolumn{4}{|c|}{$\begin{array}{c}\text { Rest of Canada } \\
\text { (with Ontario, Nova Scotia, } \\
\text { Newfoundland and Labrador excluded) }\end{array}$} \\
\hline & \multicolumn{2}{|c|}{ Before 1989} & \multicolumn{2}{|c|}{ After 1989} & \multicolumn{2}{|c|}{ Before 1989} & \multicolumn{2}{|c|}{ After 1989} \\
\hline & Mean & Std. Dev. & Mean & Std. Dev. & Mean & Std. Dev. & Mean & Std. Dev. \\
\hline Married/Common-law \% & 64.08 & 0.48 & 63.57 & 0.48 & 63.68 & 0.48 & 63.30 & 0.48 \\
\hline Divorced/Separated \% & 5.89 & 0.24 & 7.14 & 0.26 & 6.58 & 0.25 & 7.23 & 0.26 \\
\hline Single $\%$ & 24.13 & 0.43 & 23.33 & 0.42 & 24.08 & 0.43 & 23.94 & 0.43 \\
\hline Female $\%$ & 51.07 & 0.50 & 51.00 & 0.50 & 50.13 & 0.50 & 50.22 & 0.50 \\
\hline Age & 41.52 & 16.84 & 42.85 & 16.73 & 41.50 & 17.45 & 42.66 & 17.34 \\
\hline High school or less $\%$ & 68.34 & 0.47 & 55.60 & 0.50 & 63.81 & 0.48 & 52.20 & 0.50 \\
\hline First child 5 years or above $\%$ & 33.40 & 0.47 & 32.22 & 0.47 & 31.26 & 0.46 & 30.97 & 0.46 \\
\hline No child $\%$ & 57.48 & 0.49 & 59.06 & 0.49 & 59.41 & 0.49 & 60.65 & 0.49 \\
\hline Children under 5 years \% & 12.56 & 0.33 & 12.11 & 0.33 & 13.87 & 0.35 & 12.72 & 0.33 \\
\hline Labour force participation \% & 65.04 & 0.48 & 64.35 & 0.48 & 68.84 & 0.46 & 68.98 & 0.46 \\
\hline Hours of work (per week) & 22.30 & 21.09 & 21.50 & 21.03 & 24.50 & 22.63 & 24.80 & 22.65 \\
\hline
\end{tabular}

Sources: Authors' calculations based on the Labour Force Survey (LFS), 1985 - 1995.

Table 2: Family Patrimony Rules Effects on Married Women's Labour Supply (Clustered Standard Errors in Parentheses)

\begin{tabular}{|c|c|c|c|c|c|}
\hline Intensive margin (Weekly hours worked): $\mathrm{T}^{*}$ After & OLS & Tobit & Heckman & UQ Median & $\mathrm{N}$ \\
\hline All married women & $\begin{array}{c}\text { Coefficient } \\
-0.43 \\
(0.27)\end{array}$ & $\begin{array}{c}\text { Coefficient } \\
-0.38^{* * *} \\
(0.07)\end{array}$ & $\begin{array}{c}\text { Coefficient } \\
-0.60 \\
(0.39)\end{array}$ & $\begin{array}{c}\text { Coefficient } \\
0.13 \\
(1.91)\end{array}$ & 252796 \\
\hline Married women in the labour force & $\begin{array}{c}-1.42^{* * *} \\
(0.31)\end{array}$ & $\begin{array}{c}-1.57^{* * *} \\
(0.33)\end{array}$ & $\begin{array}{c}-0.99^{* * *} \\
(0.29)\end{array}$ & $\begin{array}{c}-0.67^{* * *} \\
(0.24)\end{array}$ & 144952 \\
\hline Married women employed $6+$ years & $\begin{array}{l}-0.70^{*} \\
(0.37)\end{array}$ & $\begin{array}{c}-0.71^{* *} \\
(0.37)\end{array}$ & & $\begin{array}{l}-0.14 \\
(0.29)\end{array}$ & 64461 \\
\hline Extensive margin (Labour force participation): & LPM & Logit & & & \\
\hline All married women & $\begin{array}{c}\text { Coefficient } \\
0.01 \\
(0.01)\end{array}$ & $\begin{array}{c}\text { Coefficient } \\
0.04 \\
(0.04)\end{array}$ & & & 252796 \\
\hline
\end{tabular}

* Significance at $10 \% * *$ Significance at $5 \% * * *$ Significance at $1 \%$

Note: The full set of controls includes age dummies, whether they have children or not, whether they have children under five years, whether they have a high school degree or less, the age of their first child dummies, year-by-month fixed effects, province fixed effects, province-by-time fixed effects. Standard errors in parentheses are clustered at the province-by-time level.

Sources: Authors' calculations based on the Labour Force Survey (LFS), 1985 - 1995. 


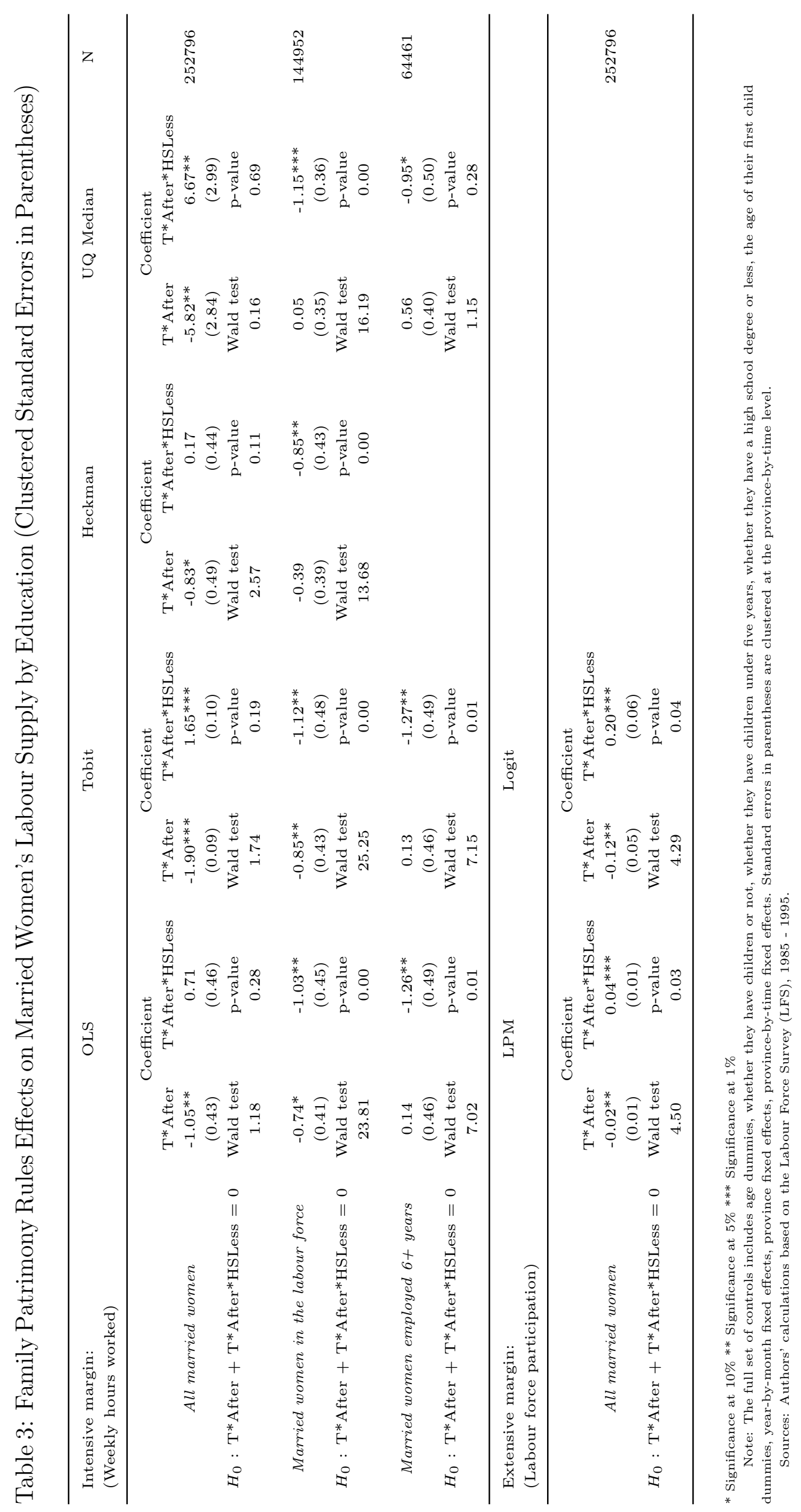




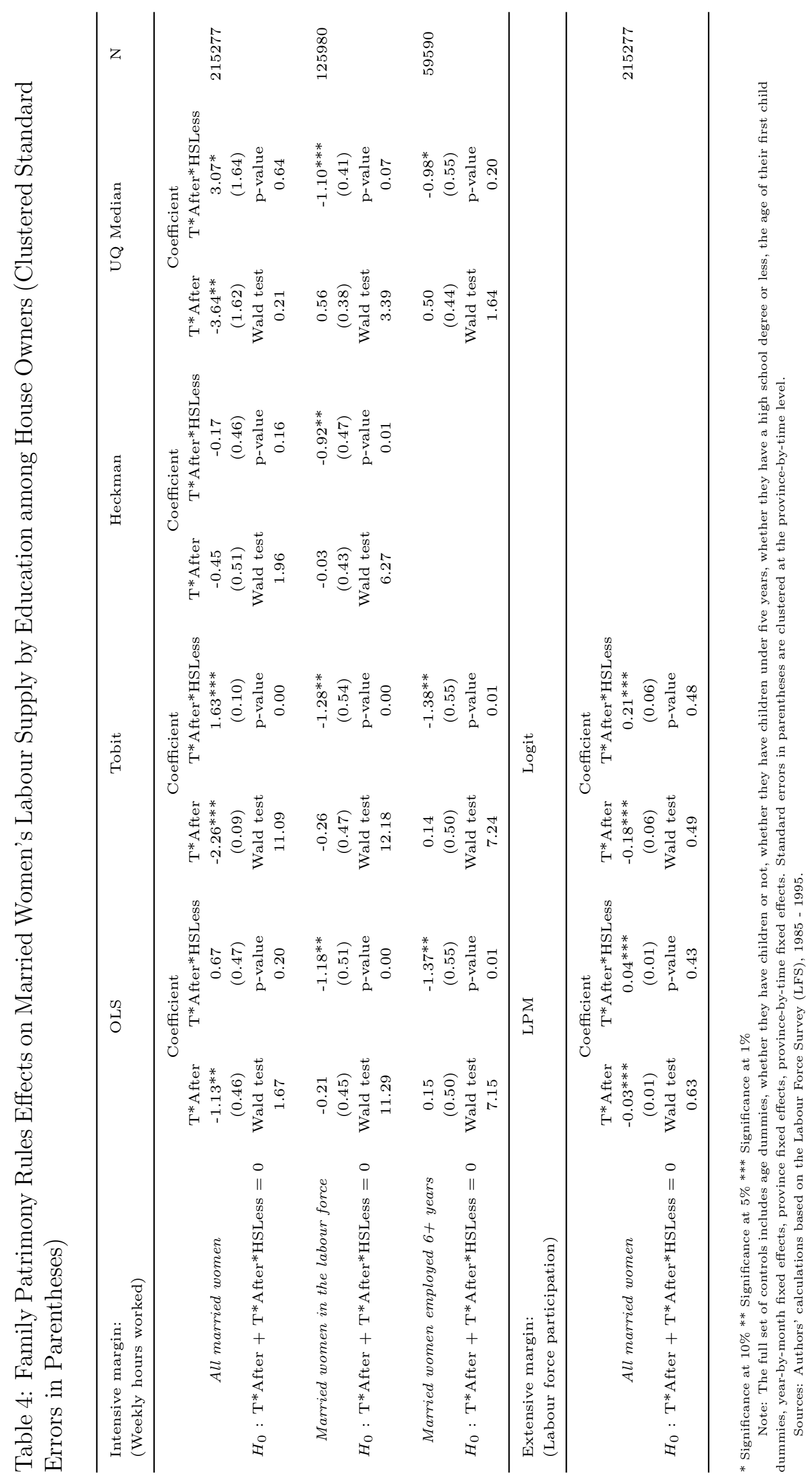


Table 5: Impact of the Quebec Family Patrimony Rules on Divorce Transitions (Clustered Standard Errors in Parentheses)

\begin{tabular}{|c|c|c|c|}
\hline All & \multicolumn{3}{|c|}{$\begin{array}{c}\text { by Differential Education } \\
\text { between Spouses }\end{array}$} \\
\hline $\begin{array}{c}\text { Quebec*After } \\
0.76 \\
(0.52)\end{array}$ & $\begin{array}{c}\text { Quebec*After } \\
0.79 \\
(0.64)\end{array}$ & $\begin{array}{c}\text { Quebec*After*Less } \\
0.40 \\
(0.55)\end{array}$ & $\begin{array}{c}\text { Quebec*After*More } \\
-0.22 \\
(0.46)\end{array}$ \\
\hline $\mathrm{N}$ & $\begin{array}{c}H_{0}: \text { Quebec*}^{*} A \\
\text { Wald test } \\
\text { p-value }\end{array}$ & $\begin{array}{cc}\text { fter }+ \text { Quebec*After* } & \text { * } \\
1.88 & \\
0.06 & \\
& 309081\end{array}$ & $\begin{array}{c}\text { /Quebec*After*More }= \\
1.12 \\
0.27\end{array}$ \\
\hline
\end{tabular}

* Significance at $10 \% * *$ Significance at $5 \% * * *$ Significance at $1 \%$

Note: The controls include age dummies, sex, whether they have a high school degree or less, year-bymonth fixed effects, province fixed effects, province-by-time fixed effects. Standard errors are clustered at the province-by-time level.

Sources: Authors' calculations based on the Labour Force Survey (LFS), 1985 - 1995.

Table 6: Summary Statistics of Respondents' Education in Quebec and Other Provinces in Pre and Post Intervention Years by Gender

\begin{tabular}{lc|c|c|c|c|c}
\hline High school or less \% & \multicolumn{3}{c|}{ Female } & \multicolumn{3}{c}{ Male } \\
\hline & Before 1989 & After 1989 & \% change & Before 1989 & After 1989 & \% change \\
\hline Quebec & 70.04 & 57.67 & 12.37 & 66.54 & 53.40 & 13.14 \\
Rest of Canada & 64.32 & 53.20 & 11.12 & 63.34 & 51.21 & 12.13 \\
\hline
\end{tabular}

Sources: Authors' calculations based on the Labour Force Survey (LFS), 1985 - 1995.

Table 7: Differential Educational Attainment Between Spouses

\begin{tabular}{ccl}
\hline Differential Educational Attainment & Husband's Education & \multicolumn{1}{c}{ Wife's Education } \\
\hline-1 & Have High School or Less & More Than High School \\
\hline 0 & Have High School or Less & $\begin{array}{l}\text { Have High School or Less } \\
\text { or } \\
\text { More Than High School }\end{array}$ \\
\hline 1 & More Than High School & Have High School or Less \\
\hline
\end{tabular}


Table 8: Multinomial Logistic Regression of the Differential Educational Attainment between Spouses (Clustered Standard Errors in Parentheses)

\begin{tabular}{cccc}
\hline \multicolumn{3}{c}{ Base Outcome } \\
\hline & Both more-educated or both less-educated & Both more-educated & Both less-educated \\
\hline Differential Education & Coefficient & Coefficient & Coefficient \\
between Spouses & $\mathrm{T}^{*}$ After & $\mathrm{T}^{*}$ After & $\mathrm{T}^{*}$ After \\
-1 versus 0 & $0.21^{* * *}$ & 0.12 & $0.32^{* * *}$ \\
& $(0.08)$ & $(0.09)$ & $(0.08)$ \\
1 versus 0 & -0.05 & $-0.15^{*}$ & 0.06 \\
& $(0.08)$ & $(0.09)$ & $(0.09)$ \\
$\mathrm{N}$ & 211913 & 122193 & 153486 \\
\hline
\end{tabular}

* Significance at $10 \% * *$ Significance at $5 \% * * *$ Significance at $1 \%$

Note: The controls include year-by-month fixed effects, province fixed effects, province-by-time fixed effects. Standard errors in parentheses are clustered at the province-by-time level.

Sources: Authors' calculations based on the Labour Force Survey (LFS), 1985 - 1995. 


\title{
Appendix
}

\section{Appendix A: Summary of Marital Property Law in Each Province in 1989}

\author{
Table A1: Summary of Marital Property Law in Each Province in 1989 \\ (Compiled from the sites listed at end)
}

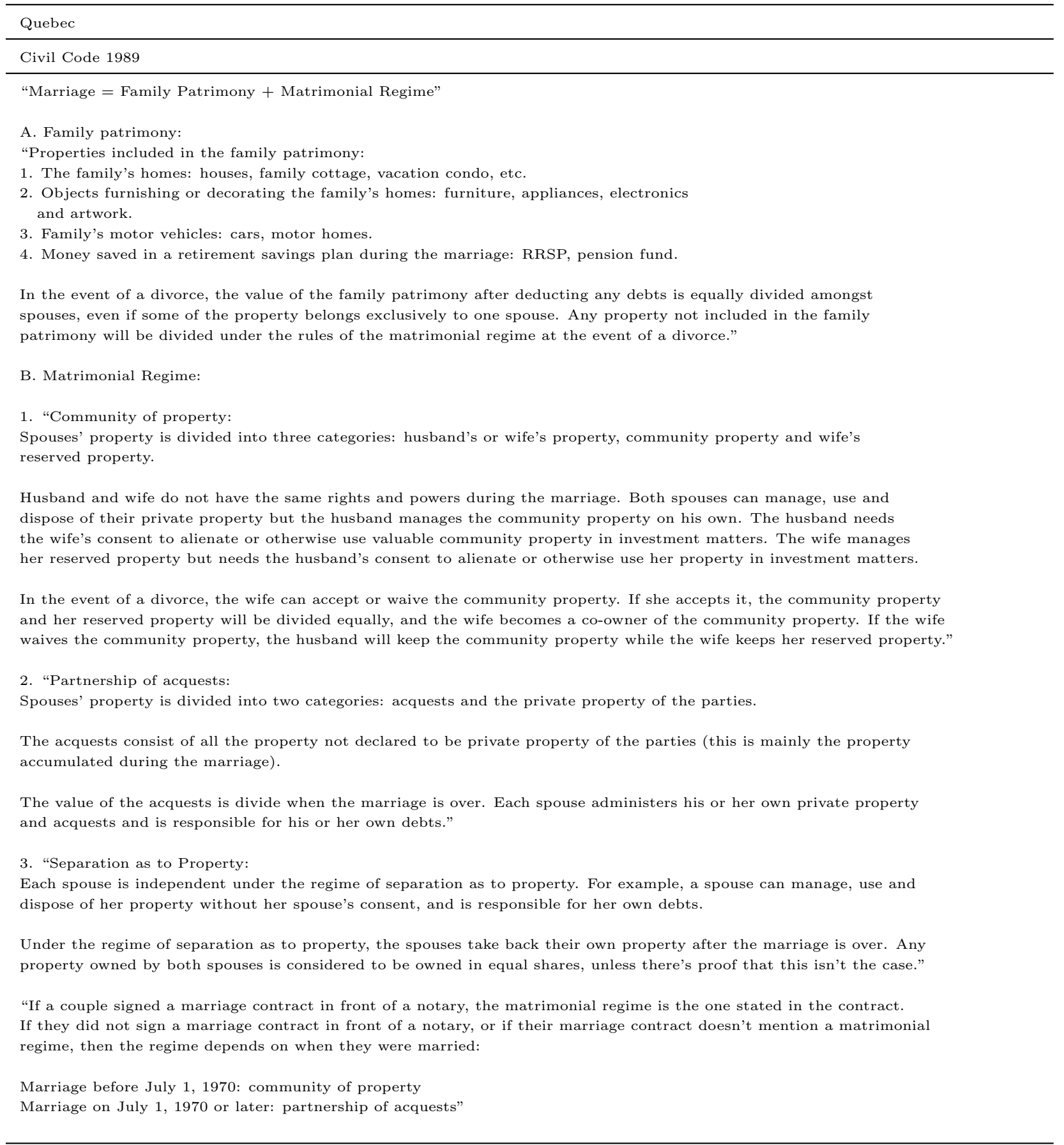




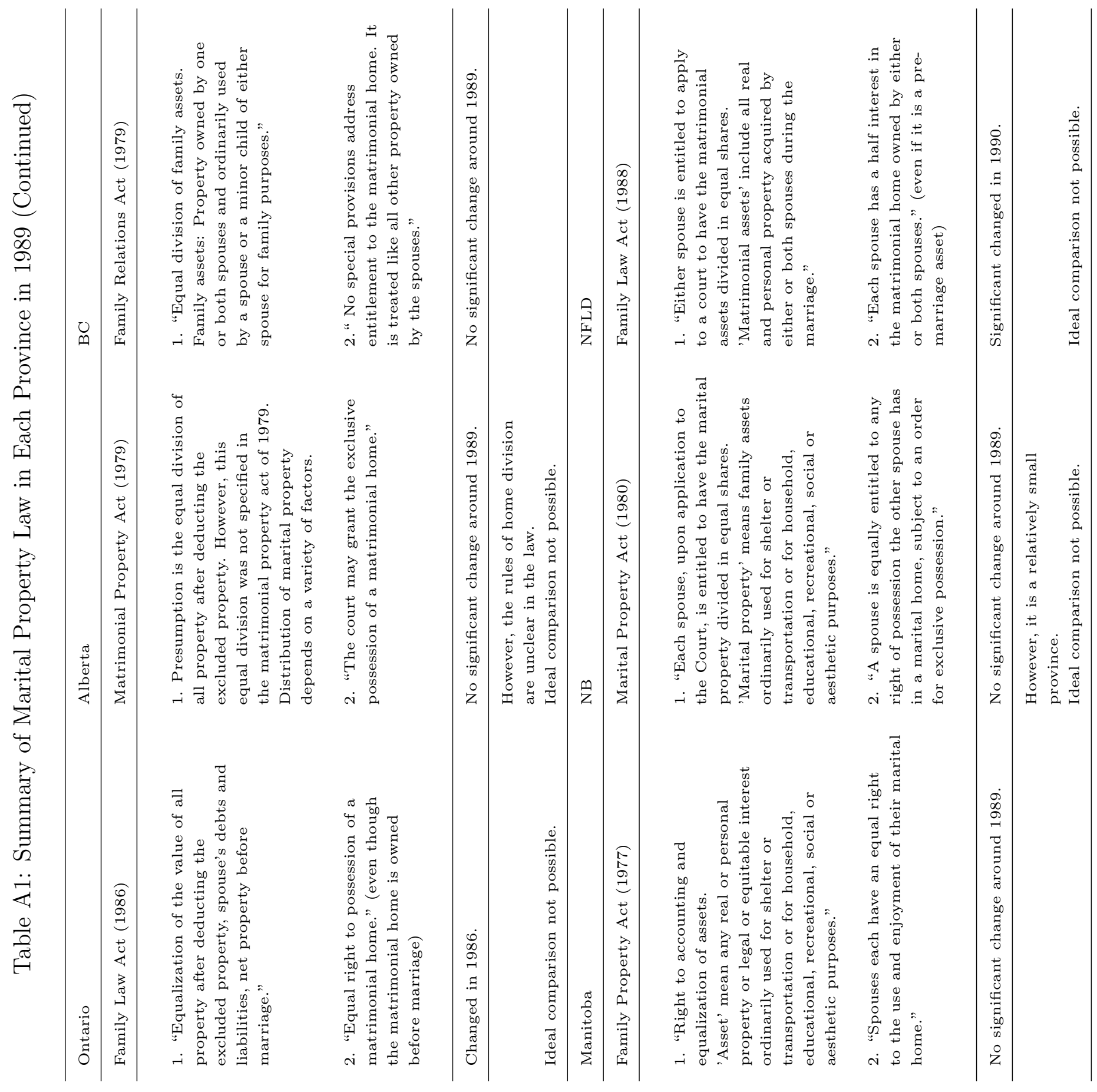




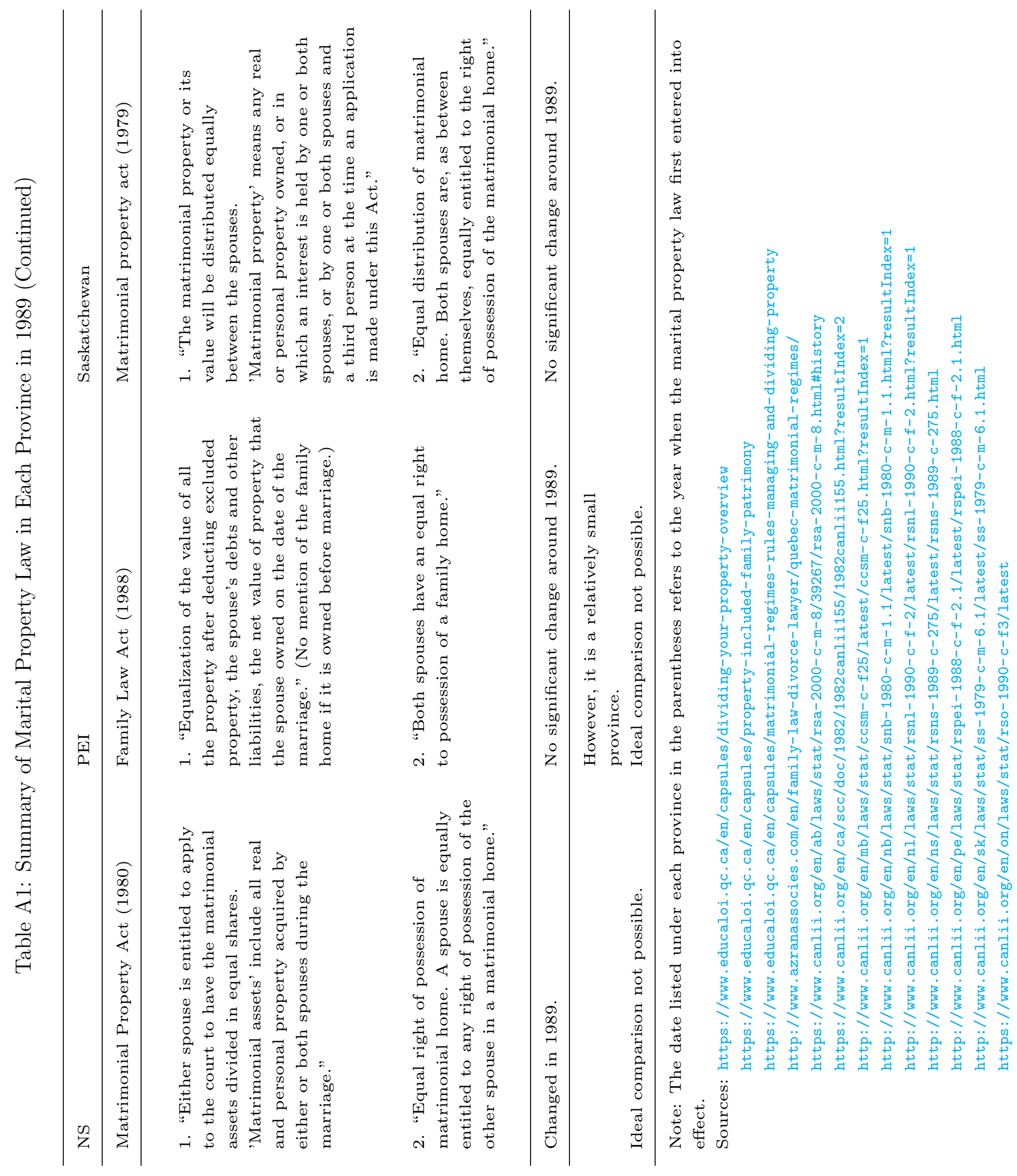




\section{Appendix B: DiD Approach Summary and Tests}

Table B1: Difference-in-Difference Framework for the Analysis of Married Women's Labour Supply

\begin{tabular}{|c|c|c|}
\hline & before 1989 & after 1989 \\
\hline Treatment Group & $\begin{array}{l}\text { Women married/cohabited before } 1989 \\
\text { with children in Quebec } \\
\text { (first children aged } 5 \text { years or above) } \\
\text { Women married/cohabited before } 1989 \\
\text { without children in Quebec } \\
\text { (age }>40)\end{array}$ & $\begin{array}{l}\text { Women married/cohabited before } 1989 \\
\text { with children in Quebec } \\
\text { (first children aged } 5 \text { years or above) } \\
\text { Women married/cohabited before } 1989 \\
\text { without children in Quebec } \\
\text { (age }>40)\end{array}$ \\
\hline Control Group & $\begin{array}{l}\text { Women married/cohabited before } 1989 \\
\text { with children in other provinces } \\
\text { (first children aged } 5 \text { years or above) } \\
\text { Women married/cohabited before } 1989 \\
\text { without children in other provinces } \\
\text { (age }>40)\end{array}$ & $\begin{array}{l}\text { Women married/cohabited before } 1989 \\
\text { with children in other provinces } \\
\text { (first children aged } 5 \text { years or above) } \\
\text { Women married/cohabited before } 1989 \\
\text { without children in other provinces } \\
\text { (age }>40)\end{array}$ \\
\hline
\end{tabular}

Table B2: Test of the Parallel Trends Assumption

\begin{tabular}{ccccc}
\hline & Hours worked & LFP Rate & Divorce/Separate Rate & $\begin{array}{c}\text { Differential Education } \\
\text { between Spouses }\end{array}$ \\
\hline F-test & 0.55 & 0.32 & 0.28 & 0.17 \\
P-value & 0.65 & 0.81 & 0.84 & 0.95 \\
\hline
\end{tabular}

Sources: Authors' calculations based on the Labour Force Survey (LFS), 1985 - 1995.

Table B3: Difference-in-Difference Framework for the Analysis of Divorce Transitions

\begin{tabular}{|c|c|c|}
\hline & before 1989 & after 1989 \\
\hline $\begin{array}{l}\text { Treatment Group } \\
\qquad(\mathrm{T})\end{array}$ & $\begin{array}{c}\text { Both women and men who are married } \\
\text { in the first survey month } \\
\text { in Quebec (age }>18)\end{array}$ & $\begin{array}{c}\text { Both women and men who are married } \\
\text { in the first survey month } \\
\text { in Quebec }(\text { age }>18)\end{array}$ \\
\hline $\begin{array}{l}\text { Control Group } \\
\text { (C) }\end{array}$ & $\begin{array}{c}\text { Both women and men who are married } \\
\text { in the first survey month } \\
\text { in the other provinces }(\text { age }>18)\end{array}$ & $\begin{array}{l}\text { Both women and men who are married } \\
\text { in the first survey month } \\
\text { in the other provinces (age }>18)\end{array}$ \\
\hline
\end{tabular}


Table B4: Difference-in-Difference Framework for the Analysis of Assortative Matching

\begin{tabular}{ccc}
\hline & before 1989 & after 1989 \\
\hline $\begin{array}{c}\text { Treatment Group } \\
(\mathrm{T})\end{array}$ & $\begin{array}{c}\text { Couples married before 1989 } \\
\text { in Quebec (age } \leq 30)\end{array}$ & $\begin{array}{c}\text { Couples married after 1989 } \\
\text { in Quebec (age } \leq 30)\end{array}$ \\
\hline $\begin{array}{c}\text { Control Group } \\
(\mathrm{C})\end{array}$ & $\begin{array}{c}\text { Couples married before 1989 } \\
\text { in the other provinces }(\text { age } \leq 30)\end{array}$ & $\begin{array}{c}\text { Couples married after 1989 } \\
\text { in the other provinces (age } \leq 30)\end{array}$ \\
\hline
\end{tabular}

\section{Appendix C: Robustness Checks}

\section{Appendix C.1: Common Law Analysis}

The data used in this analysis is based on the Census, 1981, 1986, 1991 and 1996, which provide information on individuals' labour supply and marital status as well as their demographic characteristics in both pre-intervention and post-intervention periods. Table C1 below presents the Census summary statistics of our sample's basic characteristics of Quebec and the rest of Canada (with Ontario, Nova Scotia, Newfoundland and Labrador excluded), before and after the Civil Code amendment, separately.

Table C1: Summary Statistics of Respondents' Basic Characteristics in Quebec and Other Provinces in the Pre and Post Intervention Years with Census Data

\begin{tabular}{|c|c|c|c|c|c|c|c|c|}
\hline & \multicolumn{4}{|c|}{ Quebec } & \multicolumn{4}{|c|}{$\begin{array}{c}\text { Rest of Canada } \\
\text { (with Ontario, Nova Scotia, } \\
\text { Newfoundland and Labrador excluded) }\end{array}$} \\
\hline & \multicolumn{2}{|c|}{ Before 1989} & \multicolumn{2}{|c|}{ After 1989} & \multicolumn{2}{|c|}{ Before 1989} & \multicolumn{2}{|c|}{ After 1989} \\
\hline & Mean & Std. Dev. & Mean & Std. Dev. & Mean & Std. Dev. & Mean & Std. Dev. \\
\hline Married \% & 56.39 & 0.50 & 48.68 & 0.50 & 60.83 & 0.49 & 57.32 & 0.49 \\
\hline Common-law \% & 6.56 & 0.25 & 13.51 & 0.34 & 4.61 & 0.21 & 6.80 & 0.25 \\
\hline Divorced/Separated \% & 5.77 & 0.23 & 7.75 & 0.27 & 6.46 & 0.25 & 7.82 & 0.27 \\
\hline Single $\%$ & 24.59 & 0.43 & 23.72 & 0.43 & 21.32 & 0.41 & 21.72 & 0.41 \\
\hline Female $\%$ & 51.56 & 0.50 & 51.61 & 0.50 & 50.51 & 0.50 & 50.91 & 0.50 \\
\hline Age & 41.52 & 16.86 & 43.84 & 16.70 & 41.94 & 17.51 & 43.66 & 17.29 \\
\hline High school or less $\%$ & 59.05 & 0.49 & 52.31 & 0.50 & 54.47 & 0.50 & 46.38 & 0.50 \\
\hline First child 6 years or above $\%$ & 38.93 & 0.49 & 57.55 & 0.49 & 36.24 & 0.48 & 54.88 & 0.50 \\
\hline No child $\%$ & 49.11 & 0.50 & 31.54 & 0.64 & 50.02 & 0.50 & 34.34 & 0.47 \\
\hline Children under 5 years \% & 22.06 & 0.41 & 35.52 & 0.48 & 23.63 & 0.42 & 36.60 & 0.48 \\
\hline Labour force participation $\%$ & 65.01 & 0.48 & 65.88 & 0.47 & 69.09 & 0.46 & 70.28 & 0.46 \\
\hline Hours of work (per week) & 20.74 & 21.12 & 20.83 & 21.00 & 24.11 & 23.38 & 23.98 & 22.90 \\
\hline
\end{tabular}

Sources: Authors' calculations based on Canadian Censuses of population, 1981 - 1996.

We can see that the respondents in the Census show the similarity on their attributes with those in the LFS. After comparing the summary statistics of these two groups in the pre-intervention periods, we can see that, on average, Quebec has a slightly smaller proportion of married or divorced/separated people, and a slightly larger proportion of 
common-law or single people than the other provinces. The average hours of work and mean LFP rate in Quebec are slightly lower than those in the other provinces. Respondents' ages in these two groups are on average very similar. Overall, we may conclude that, before the Civil Code amendment, the Quebec sample shared attributes similar to those of the other provinces sample.

Table C2: Proportion of population aged 18 and over that lived common-law, 1981-1996

\begin{tabular}{|c|c|c|c|c|c|c|}
\hline \multirow[b]{2}{*}{$\%$} & \multicolumn{4}{|c|}{ Common-law Rate } & \multirow{2}{*}{$\begin{array}{l}\text { Difference } \\
1986-1981\end{array}$} & \multirow{2}{*}{$\begin{array}{l}\text { Difference } \\
1996-1991 \\
\end{array}$} \\
\hline & 1981 & 1986 & 1991 & 1996 & & \\
\hline Quebec & 5.22 & 7.84 & 11.99 & 14.95 & 2.62 & 2.96 \\
\hline Rest of Canada & 4.34 & 4.85 & 6.35 & 7.22 & 0.51 & 0.87 \\
\hline
\end{tabular}

Sources: Authors' calculations based on Canadian Censuses of population, 1981 - 1996. 


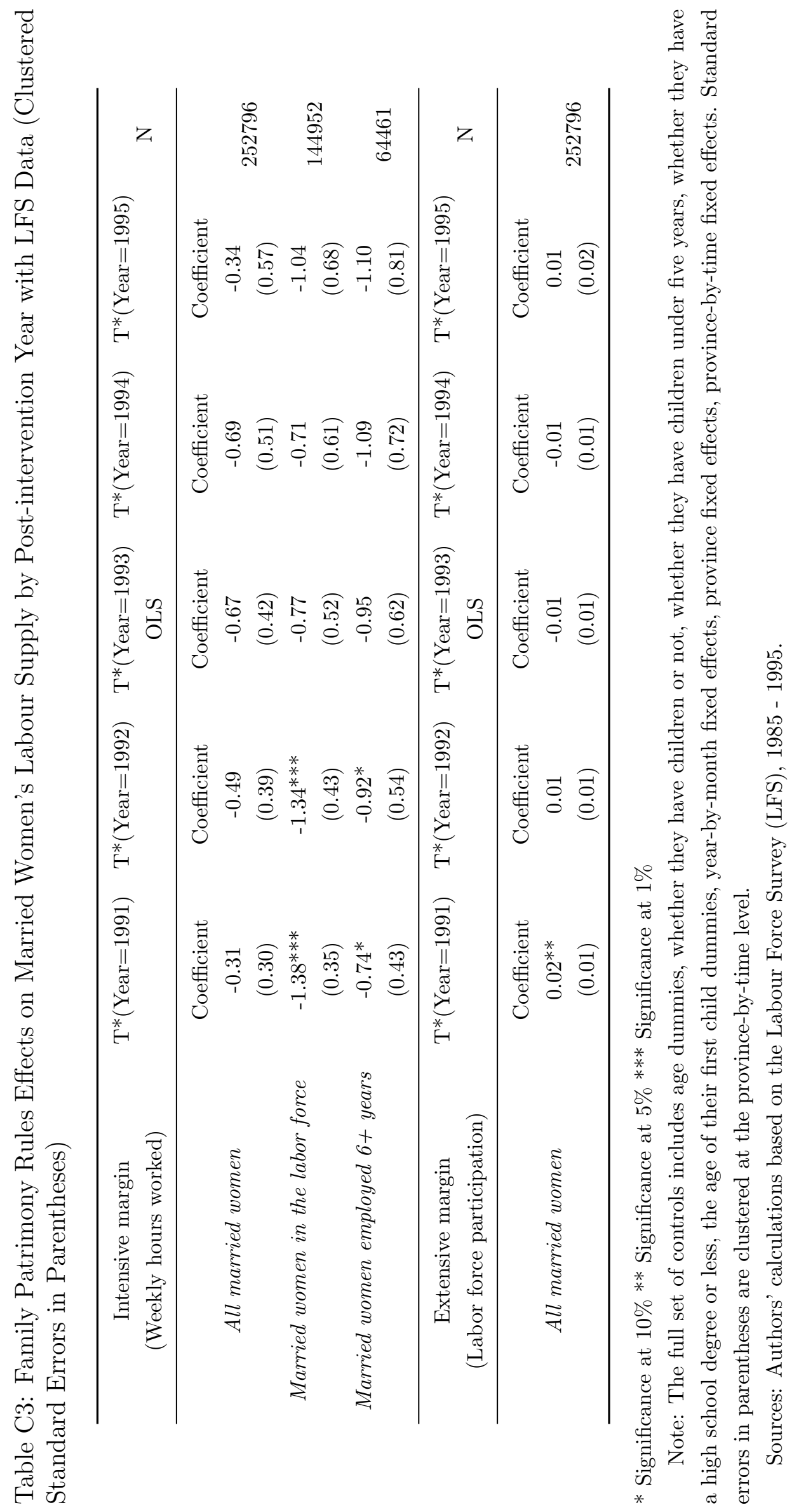




\section{Appendix C.2: Alternative Policy Changes and Falsification Checks}

Table C4: Family Patrimony Rules Effects on Married Women's Labour Supply with Control for Presence of a Newborn (Clustered Standard Errors in Parentheses)

\begin{tabular}{|c|c|c|c|c|c|}
\hline Intensive margin (Weekly hours worked): $\mathrm{T}^{*}$ After & OLS & Tobit & Heckman & UQ Median & $\mathrm{N}$ \\
\hline All married women & $\begin{array}{c}\text { Coefficient } \\
-0.43 \\
(0.27)\end{array}$ & $\begin{array}{c}\text { Coefficient } \\
-0.37^{* * *} \\
(0.07)\end{array}$ & $\begin{array}{c}\text { Coefficient } \\
-0.60 \\
(0.39)\end{array}$ & $\begin{array}{c}\text { Coefficient } \\
0.18 \\
(1.91)\end{array}$ & 252796 \\
\hline Married women in the labour force & $\begin{array}{c}-1.42^{* * *} \\
(0.31)\end{array}$ & $\begin{array}{c}-1.57^{* * *} \\
(0.33)\end{array}$ & $\begin{array}{c}-0.99 * * * \\
(0.29)\end{array}$ & $\begin{array}{c}-0.68^{* * *} \\
(0.24)\end{array}$ & 144952 \\
\hline Married women employed $6+$ years & $\begin{array}{c}-0.70^{*} \\
(0.37)\end{array}$ & $\begin{array}{c}-0.71^{*} \\
(0.37)\end{array}$ & & $\begin{array}{l}-0.14 \\
(0.29)\end{array}$ & 64461 \\
\hline Extensive margin (Labour force participation): & LPM & Logit & & & \\
\hline All married women & $\begin{array}{c}\text { Coefficient } \\
0.01 \\
(0.01)\end{array}$ & $\begin{array}{c}\text { Coefficient } \\
0.05 \\
(0.04)\end{array}$ & & & 252796 \\
\hline
\end{tabular}

* Significance at $10 \% * *$ Significance at $5 \% * * *$ Significance at $1 \%$

Note: The full set of controls includes age dummies, whether they have children or not, whether they have children under five years, whether they have a newborn or not, whether they have a high school degree or less, the age of their first child dummies, year-by-month fixed effects, province fixed effects, province-by-time fixed effects. Standard errors in parentheses are clustered at the province-by-time level.

Sources: Authors' calculations based on the Labour Force Survey (LFS), 1985 - 1995. 


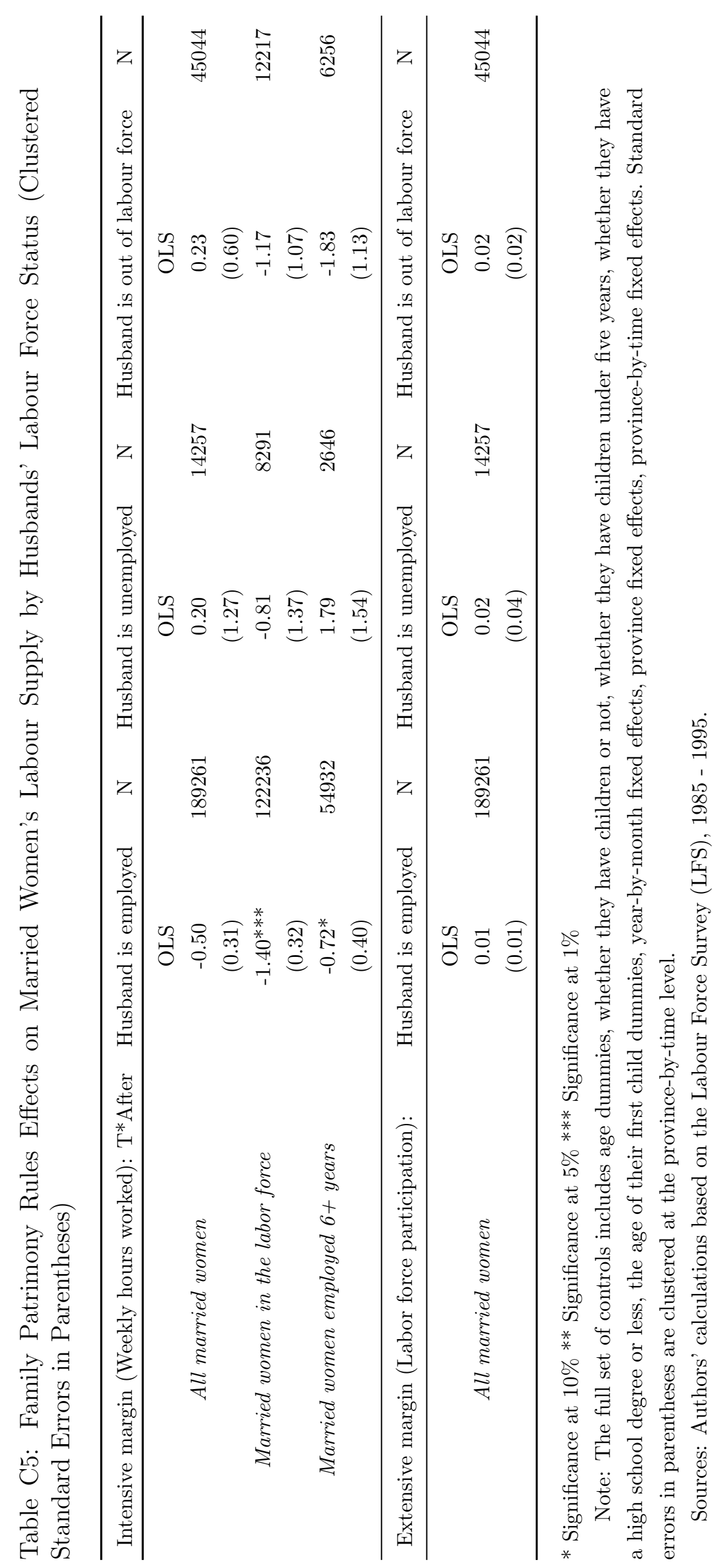


Table C6: Effect of Family Patrimony Rules on Married Women's Labour Supply among House Owners (Clustered Standard Errors in Parentheses)

\begin{tabular}{cccccc}
\hline Intensive margin (Weekly hours worked): T*After & OLS & Tobit & Heckman & UQ Median & $\mathrm{N}$ \\
\hline All married women & Coefficient & Coefficient & Coefficient & Coefficient & \\
& -0.53 & -0.70 & -0.43 & -0.72 & 215277 \\
Married women in the labour force & $(0.33)$ & $(0.58)$ & $(0.41)$ & $(1.13)$ & \\
& $-0.94^{* * *}$ & $-1.04^{* * *}$ & $-0.65^{* *}$ & -0.09 & 125980 \\
Married women employed 6+ years & $(0.35)$ & $(0.37)$ & $(0.33)$ & $(0.26)$ & \\
& $-0.74^{*}$ & $-0.75^{*}$ & & -0.23 & 59590 \\
\hline Extensive margin (Labour force participation): & $(0.39)$ & $(0.39)$ & & $(0.31)$ & \\
\hline & LPM & Logit & & & \\
All married women & Coefficient & Coefficient & & & \\
& 0.00 & -0.01 & & & \\
\hline
\end{tabular}

* Significance at $10 \% * *$ Significance at $5 \% * * *$ Significance at $1 \%$

Note: The full set of controls includes age dummies, whether they have children or not, whether they have children under five years, whether they have a high school degree or less, the age of their first child dummies, year-by-month fixed effects, province fixed effects, province-by-time fixed effects. Standard errors in parentheses are clustered at the province-by-time level.

Sources: Authors' calculations based on the Labour Force Survey (LFS), 1985 - 1995. 
As an additional robustness check, we impose a "false" treatment in 1989 among single women in Quebec and explore their responsiveness to this policy change using the LFS, 1985-1995. The age restriction (age $>30$ ) is imposed due to the childless social assistance reform in Quebec which is mentioned before. Also, we excluded women who indicate they are full-time students to avoid capturing labour supply effects associated with seasonal part-time work fluctuations.

Table C7 indicates the effects of Quebec's family patrimony rules on single women's labour supply using Equation 2 at both intensive and extensive margins $\left(T_{i p}\right.$ takes value 1 for single women living in Quebec, while takes value 0 for single women living in the other provinces.). As we expected, single women in Quebec did not respond to the family patrimony rules since the coefficients of $T_{i p} * A f t e r_{t}$ are small and statistically insignificant in all the estimations.

Table C7: Effect of Family Patrimony Rules on Single Women's Labour Supply with LFS Data (Clustered Standard Errors in Parentheses)

\begin{tabular}{|c|c|c|c|c|c|c|}
\hline $\begin{array}{l}\text { Intensive margin: T*After } \\
\text { (Weekly hours worked) }\end{array}$ & $\begin{array}{c}\text { All } \\
\text { OLS }\end{array}$ & $\mathrm{N}$ & $\begin{array}{l}\text { More-educated } \\
\text { OLS }\end{array}$ & $\mathrm{N}$ & $\begin{array}{l}\text { Ever worked full-time } \\
\text { OLS }\end{array}$ & $\mathrm{N}$ \\
\hline & Coefficient & & Coefficient & & Coefficient & \\
\hline All single women & $\begin{array}{l}-0.46 \\
(0.77)\end{array}$ & 30704 & $\begin{array}{l}-0.37 \\
(1.30)\end{array}$ & 14404 & $\begin{array}{l}-0.74 \\
(0.79)\end{array}$ & 19132 \\
\hline Single women in the labor force & $\begin{array}{l}-0.62 \\
(0.74)\end{array}$ & 19573 & $\begin{array}{l}-0.67 \\
(1.01)\end{array}$ & 11690 & $\begin{array}{l}-0.47 \\
(0.69)\end{array}$ & 17712 \\
\hline Single women employed $6+$ year & $\begin{array}{l}-0.09 \\
(0.66)\end{array}$ & 8994 & $\begin{array}{c}1.03 \\
(0.81)\end{array}$ & 5612 & $\begin{array}{l}-0.31 \\
(0.56)\end{array}$ & 8828 \\
\hline $\begin{array}{l}\text { Extensive margin: } \mathrm{T}^{*} \text { After } \\
\text { (Labor force participation) }\end{array}$ & $\begin{array}{c}\text { All } \\
\text { OLS }\end{array}$ & $\mathrm{N}$ & $\begin{array}{l}\text { More-educated } \\
\quad \text { OLS }\end{array}$ & $\mathrm{N}$ & $\begin{array}{l}\text { Ever worked full-time } \\
\text { OLS }\end{array}$ & $\mathrm{N}$ \\
\hline All single women & $\begin{array}{c}\text { Coefficient } \\
-0.01 \\
(0.02)\end{array}$ & 30704 & $\begin{array}{c}\text { Coefficient } \\
0.01 \\
(0.03)\end{array}$ & 14404 & $\begin{array}{c}\text { Coefficient } \\
-0.01 \\
(0.01)\end{array}$ & 19132 \\
\hline
\end{tabular}

* Significance at $10 \% * *$ Significance at $5 \% * * *$ Significance at $1 \%$

Note: The full set of controls includes age dummies, whether they have children or not, whether they have children under five years, whether they have a high school degree or less, year-by-month fixed effects, province fixed effects, province-by-time fixed effects. Standard errors in parentheses are clustered at the province-by-time level.

Sources: Authors' calculations based on the Labour Force Survey (LFS), 1985 - 1995. 


\section{Bibliography}

Agarwal, B. (1997): "Bargaining and gender relations: Within and beyond the household," Feminist economics, 3, 1-51.

Allen, D. W. (1998): "No-fault divorce in Canada: Its cause and effect," Journal of Economic Behavior \& Organization, 37, 129-149.

Angrist, J. D. AND J.-S. PischKe (2009): Mostly harmless econometrics: An empiricist's companion, Princeton university press.

Athey, S. And G. W. Imbens (2006): "Identification and inference in nonlinear difference-in-differences models," Econometrica, 74, 431-497.

BAKER, M. (1994): "Family and population policy in Quebec: Implications for women," Can. J. Women \& L., 7, 116.

BECKER, G. S. (1974): "A theory of social interactions," Journal of political economy, 82, 1063-1093.

Bedard, K. And O. Deschenes (2005): "Sex preferences, marital dissolution, and the economic status of women," Journal of human Resources, 40, 411-434.

Bertrand, M., E. Duflo, And S. Mullainathan (2004): "How much should we trust differences-in-differences estimates?" The Quarterly journal of economics, 119, 249-275.

Blundell, R., P.-A. Chiappori, T. Magnac, And C. Meghir (2007): "Collective labour supply: Heterogeneity and non-participation," The Review of Economic Studies, $74,417-445$.

Brassiolo, P. (2013): "The effect of property division laws on divorce and labor supply: evidence from Spain," .

Browning, M. And P.-A. Chiappori (1998): "Efficient intra-household allocations: A general characterization and empirical tests," Econometrica, 1241-1278.

BuIS, M. L. ET AL. (2010): "Stata tip 87: Interpretation of interactions in non-linear models," The stata journal, 10, 305-308.

Cameron, A. C. And D. L. Miller (2015): "A practitioner's guide to cluster-robust inference," Journal of Human Resources, 50, 317-372.

CanadA, 1988. BILl S-3.1.1.: "Act Respecting Income Security, LegisQuebec," Retrieved at http://legisquebec.gouv.qc.ca/en/ShowDoc/cs/S-3.1.1. 
Canadian Social Research Links(1998): "Overview of Provincial Welfare Reforms in the 1990s" Retrieved at http://canadiansocialresearch.net/1990s_welfare_ reforms.htm

Chiappori, P.-A. (1988): "Rational household labor supply," Econometrica: Journal of the Econometric Society, 63-90.

(1992): "Collective labor supply and welfare," Journal of political Economy, 100, $437-467$.

Chiappori, P.-A. AND I. Ekeland (2001): "The microeconomics of group behavior," Manuscript. Chicago: Univ. Chicago.

Chiappori, P.-A., B. Fortin, And G. Lacroix (2002): "Marriage market, divorce legislation, and household labor supply," Journal of political Economy, 110, 37-72.

Chiappori, P.-A., M. Iriyigun, And Y. Weiss (2005): "Marriage Markets, Divorce and Intra-Household Allocations," Tech. rep., University of Colorado working paper.

Chiappori, P.-A., M. Iyigun, J. Lafortune, And Y. Weiss (2017): "Changing the rules midway: the impact of granting alimony rights on existing and newly formed partnerships," The Economic Journal, 127, 1874-1905.

Donald, S. G. And K. LAng (2007): "Inference with difference-in-differences and other panel data," The review of Economics and Statistics, 89, 221-233.

Firpo, S., N. M. Fortin, And T. Lemieux (2009): "Unconditional quantile regressions," Econometrica, 77, 953-973.

FriedBerG, L. (1998): "Did unilateral divorce raise divorce rates? Evidence from panel data," Tech. rep., National Bureau of Economic Research.

Genadek, K. R., W. A. Stock, And C. Stoddard (2007): "No-fault divorce laws and the labor supply of women with and without children," Journal of Human Resources, 42, $247-274$.

GonzÁlez, L. And T. K. Vittanen (2009): "The effect of divorce laws on divorce rates in Europe," European Economic Review, 53, 127-138.

Goussé, M., N. Jacquemet, And J.-M. Robin (2017): "Marriage, labor supply, and home production," Econometrica, 85, 1873-1919.

Gray, J. S. (1998): "Divorce-law changes, household bargaining, and married women's labor supply," The American Economic Review, 88, 628-642. 
HeCKMAN, J. J. (1977): "Sample selection bias as a specification error (with an application to the estimation of labor supply functions)," .

Hoddinott, J. And L. Haddad (1995): "Does female income share influence household expenditures? Evidence from Côte d'Ivoire," oxford Bulletin of Economics and Statistics, $57,77-96$.

Horvath, F. W. (1982): "Forgotten unemployment: recall bias in retrospective data," Monthly Labor Review, 105, 40-43.

Kalmisn, M. (1994): "Assortative mating by cultural and economic occupational status," American Journal of sociology, 100, 422-452.

KAPAn, T. ET AL. (2008): "Property division laws: the effects on labor supply and household bargaining," Ph.D. thesis, PhD Thesis, Columbia University.

Karaca-Mandic, P., E. C. Norton, And B. Dowd (2012): "Interaction terms in nonlinear models," Health services research, 47, 255-274.

Koebel, K. And T. Schirle (2016): "The differential impact of universal child benefits on the labour supply of married and single mothers," Canadian Public Policy, 42, 49-64.

Le Bourdais, C. AND É. LAPIERRE-AdAmCYK (2004): "Changes in conjugal life in Canada: Is cohabitation progressively replacing marriage?" Journal of Marriage and Family, 66, 929-942.

LECHNER, M. ET AL. (2011): "The estimation of causal effects by difference-in-difference methods," Foundations and Trends@ in Econometrics, 4, 165-224.

Lemieux, T. And K. Milligan (2008): "Incentive effects of social assistance: A regression discontinuity approach," Journal of Econometrics, 142, 807-828.

Ligon, E. A., J. Hoddinott, And C. AdAm (2003): "Dynamic intrahousehold bargaining, matrimonial property law and suicide in Canada," .

Lundberg, S. J., R. A. Pollak, And T. J. Wales (1997): "Do husbands and wives pool their resources? Evidence from the United Kingdom child benefit," Journal of Human resources, 463-480.

Manser, M. And M. Brown (1980): "Marriage and household decision-making: A bargaining analysis," International economic review, 31-44.

MARE, R. D. (1991): "Five decades of educational assortative mating," American sociological review, 15-32. 
McElroy, M. B. AND M. J. Horney (1981): "Nash-bargained household decisions: Toward a generalization of the theory of demand," International economic review, 333349.

Milligan, K. (2002): "Quebec's baby bonus: can public policy raise fertility," Backgrounder-CD Howe Institute, 1.

PArkman, A. M. (1992): "Unilateral divorce and the labor-force participation rate of married women, revisited," The American Economic Review, 82, 671-678.

PAull, G. (2002): "Biases in the reporting of labour market dynamics," Tech. rep., IFS Working Papers, Institute for Fiscal Studies (IFS).

PencAvel, J. (1998): "Assortative mating by schooling and the work behavior of wives and husbands," The American Economic Review, 88, 326-329.

Peters, H. E. (1986): "Marriage and divorce: Informational constraints and private contracting," The American Economic Review, 76, 437-454.

Puhani, P. A. (2012): "The treatment effect, the cross difference, and the interaction term in nonlinear "difference-in-differences" models," Economics Letters, 115, 85-87.

Reynoso, A. (2018): "The impact of divorce laws on the equilibrium in the marriage market," Unpublished manuscript.

Sable, M. R. (1999): "Pregnancy intentions may not be a useful measure for research on maternal and child health outcomes," Perspectives on Sexual and Reproductive Health, $31,249$.

Samuelson, P. A. (1956): "Social indifference curves," The Quarterly Journal of Economics, 70, 1-22.

Schirle, T. (2015): "The effect of universal child benefits on labour supply," Canadian Journal of Economics/Revue canadienne d'économique, 48, 437-463.

Schultz, T. P. (1990): "Testing the neoclassical model of family labor supply and fertility," Journal of Human resources, 599-634.

Simard-Duplain, G. (2018): "The effect of divorce on women's labour supply: A life-cycle perspective," .

Smock, P. J., W. D. Manning, And S. Gupta (1999): "The effect of marriage and divorce on women's economic well-being," American Sociological Review, 794-812. 
Statistics Canada, The Daily.(1997): "1996 Census: Marital status, commonlaw unions and families" Retrieved at https://www150.statcan.gc.ca/n1/ daily-quotidien/971014/dq971014-eng.htm\#ART1

Stevenson, B. (2007): "The impact of divorce laws on marriage-specific capital," Journal of Labor Economics, 25, 75-94.

Stevenson, B. (2008): "Divorce law and women's labor supply," Journal of Empirical Legal Studies, 5, 853-873.

Thomas, D. (1990): "Intra-household resource allocation: An inferential approach," Journal of human resources, 635-664.

Voena, A. (2015): "Yours, Mine, and Ours: Do Divorce Laws Affect the Intertemporal Behavior of Married Couples?" American Economic Review, 105, 2295-2332.

WARD-BATts, J. (2008): "Out of the wallet and into the purse using micro data to test income pooling," Journal of human resources, 43, 325-351.

Watson, D., E. C. Klohnen, A. Casillas, E. Nus Simms, J. Haig, and D. S. BERRY (2004): "Match makers and deal breakers: Analyses of assortative mating in newlywed couples," Journal of personality, 72, 1029-1068.

ZipARo, R. (2017): "The Impact of the Matrimonial Regime on Female Education and Labor Supply: Theory and Evidence from a Natural Experiment in France," in PET 16-Rio. 